Review

\title{
Impact of Protein Intake in Older Adults with Sarcopenia and Obesity: A Gut Microbiota Perspective
}

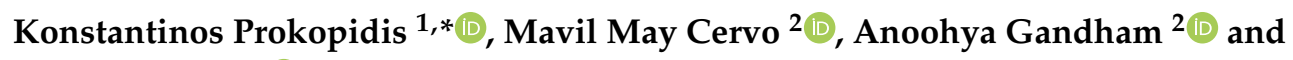 \\ David Scott ${ }^{2,3,4}$ (D)
}

1 Department of Digestion, Absorption and Reproduction, Faculty of Medicine, Imperial College London, White City, London W12 0NN, UK

2 Department of Medicine, School of Clinical Sciences at Monash Health, Monash University, 3168 Clayton, VIC, Australia; mavil.cervo@monash.edu (M.M.C.); anoohya.gandham@monash.edu (A.G.); d.scott@deakin.edu.au (D.S.)

3 Institute for Physical Activity and Nutrition, School of Exercise and Nutrition Sciences, Deakin University, 3125 Burwood, VIC, Australia

4 Department of Medicine and Australian Institute of Musculoskeletal Science, Melbourne Medical School-Western Campus, The University of Melbourne, 3021 St Albans, VIC, Australia

* Correspondence: k.prokopidis18@imperial.ac.uk

Received: 10 July 2020; Accepted: 28 July 2020; Published: 30 July 2020

check for updates

\begin{abstract}
The continuous population increase of older adults with metabolic diseases may contribute to increased prevalence of sarcopenia and obesity and requires advocacy of optimal nutrition treatments to combat their deleterious outcomes. Sarcopenic obesity, characterized by age-induced skeletal-muscle atrophy and increased adiposity, may accelerate functional decline and increase the risk of disability and mortality. In this review, we explore the influence of dietary protein on the gut microbiome and its impact on sarcopenia and obesity. Given the associations between red meat proteins and altered gut microbiota, a combination of plant and animal-based proteins are deemed favorable for gut microbiota eubiosis and muscle-protein synthesis. Additionally, high-protein diets with elevated essential amino-acid concentrations, alongside increased dietary fiber intake, may promote gut microbiota eubiosis, given the metabolic effects derived from short-chain fatty-acid and branched-chain fatty-acid production. In conclusion, a greater abundance of specific gut bacteria associated with increased satiation, protein synthesis, and overall metabolic health may be driven by protein and fiber consumption. This could counteract the development of sarcopenia and obesity and, therefore, represent a novel approach for dietary recommendations based on the gut microbiota profile. However, more human trials utilizing advanced metabolomic techniques to investigate the microbiome and its relationship with macronutrient intake, especially protein, are warranted.
\end{abstract}

Keywords: sarcopenia; obesity; gut microbiota; sarcopenic obesity; skeletal muscle; protein; older adults; short-chain fatty acids

\section{Introduction}

Older population numbers are expected to rise dramatically over the upcoming decades across the globe. By 2050, the worldwide population of those aged over 65 years is projected to increase by approximately $10 \%$, reaching 2.1 billion [1]. It is estimated that metabolic syndrome is prevalent in $12-26 \%$ and $12-37 \%$ of the European and Asian population, respectively [2]. Metabolic syndrome is outlined by skeletal-muscle-insulin resistance, hypertension, hyperlipidemia, and abdominal obesity [3]. In aging populations, prolonged malnutrition is linked to metabolic syndrome-related diseases, 
including sarcopenia and obesity, which may emerge from increased body fat, proinflammatory cytokines, oxidative stress, mitochondrial dysfunction, hormonal changes, and insulin resistance [4]. Sarcopenia is characterized by an age-related loss of skeletal-muscle mass and function, beginning in our 30 s and 40 s and being highly prevalent entering our sixth decade [5]. Sarcopenia is often accompanied by loss of balance, increased morbidity, and frailty due to deterioration of muscle fibers [6], restricting the ability of individuals to remain physically active, leading to subsequent disabilities and dependency $[7,8]$. The onset of sarcopenia includes inflammatory responses, oxidative stress, reduced energy expenditure, and decreased appetite $[9,10]$. Although several definitions of sarcopenia are currently available, including the recently revised European Working Group on Sarcopenia in Older People (EWGSOP) definition, the lack of a universal consensus on definition limits comparison between studies and amongst various population groups [11]. The prevalence of sarcopenia is largely influenced by the definition used, and the lack of a consensus also makes it difficult for clinicians to identify older adults at risk of this condition [12]. In addition, approximately $30 \%$ of the population globally is classified as overweight or obese, highlighting an additional public health and financial burden [13]. Obesity is caused by chronic positive energy balance, leading to increased proinflammatory cytokine expression, adipocyte and immune dysfunction, and insulin resistance, which contribute to a range of metabolic diseases [14], including type 2 diabetes and cancer [15]. A body mass index (BMI) $>30 \mathrm{~kg} / \mathrm{m}^{2}$ and a waist circumference over $102 \mathrm{~cm}$ and $88 \mathrm{~cm}$ for men and women, respectively, have been used as measures identifying obese populations [16]. In the United States, $38 \%$ of males and $39 \%$ of females over the age of 60 are considered obese [17], whereas the proportion of adults above a BMI of $25 \mathrm{~kg} / \mathrm{m}^{2}$ increased by $8 \%$ in the period of 1980-2013 [18].

Gut microbiota dysbiosis is linked to age-related systemic inflammation, leading to impaired muscle function and increased proinflammatory cytokines, which are associated with higher risk of obesity [19]. Gut microbiota dysregulation may promote the onset of sarcopenia and obesity through myostatin and atrogin-1 expression [20] and dysfunctional signaling between the enteric nervous system and the brain, respectively [21], imposing a negative impact on muscle mass and appetite. Nutrition may be a pivotal contributor to gut microbiota regulation, although different macronutrients promote distinct properties on the microbiome [22]. Short-chain fatty-acid (SCFA) production from dietary fiber is suggested as a prominent mediator of the gut microbiota through bacterial fermentation in the gastrointestinal tract, interacting with several gut-brain signaling pathways [23]. In addition, considering the skeletal muscle anabolic effects of dietary protein, induction of increased protein intakes above the recommended dietary allowance (RDA) $0.8 \mathrm{~g} / \mathrm{kg} /$ day is considered a valuable tool to counteract the gradual muscle loss and increased appetite for food [24] —a main characteristic of sarcopenic obesity. However, questions have been raised regarding the effects of dietary proteins on the gut microbiota and the health impact induced by their bioactive end-products [25].

In this review, we discuss how dietary protein may influence the gut microbiota ecosystem and its potential role in sarcopenia and obesity. We further aim to provide perspectives on novel future dietary recommendations, focusing primarily on the potential anabolic-induced effects that emerge from elevated protein and fiber consumption.

\section{Sarcopenia and Obesity}

Sarcopenia is accompanied by a greater incidence of comorbidities, including type 2 diabetes and obesity [26-28], which are indicative of the devastating effects derived by systemic inflammation and insulin resistance [29]. In obese older individuals, the catabolic-induced aging and obesogenic environments associated with sedentary behavior and malnutrition may lead to gradual fat accumulation in adipose tissue and simultaneous impaired skeletal-muscle atrophy, leading to a condition known as sarcopenic obesity [30,31]. Sarcopenic obese older adults are often perceived as "fat-frail" due to the weakness and poor mobility associated with sarcopenia potentially being exacerbated by excess bodyweight from obesity [32]. Recent evidence indicates that the coexistence of sarcopenia and obesity is associated with adverse musculoskeletal outcomes [33], accelerated functional 
decline, and worse disability compared with those with sarcopenia or obesity alone, or neither sarcopenia nor obesity [34]. This may lead to increased incidence of falls [35,36] and, combined with the apparent loss of any protective effect of obesity for fractures [37], sarcopenic obesity may perpetuate disability and poor quality of life [38]. Recently, there has been conjecture over whether high fat mass does in fact increase the risk of functional decline in older age beyond the effects of sarcopenia alone [39]. Nonetheless, urgency is required for recommendations on proper diagnosis and management of sarcopenic obesity, because each component is a potentially modifiable risk factor for poor metabolic health and mortality risk [40]. Like sarcopenia, clinical recognition of sarcopenic obesity among older patients is limited due to a lack of consensus on definitions, but presentations related to this condition will increase substantially with concurrent obesity epidemics and aging of populations internationally [31]. Currently, dietary recommendations for sarcopenic obesity involve high-protein, hypocaloric diets intended to improve body composition [31,41]. Considering that physical frailty may be a pivotal obstacle to aerobic and resistance exercise performance, greater attention should be paid to multiple domains of nutritional strategies. A developing field in the role of optimal dietary patterns for sarcopenia and obesity management is characterizing the ideal eubiosis of the gut microbiota ecosystem [42,43].

\section{Gut Microbiota and Immune and Metabolic Homeostasis}

\subsection{Types and Functions of Gut Microbiota}

The human gut is colonized by numerous microorganisms (e.g., bacteria, eukaryotic microbes, viruses, fungi, archaea), which are considered a contributor to a range of physiological functions, such as strengthening the gut integrity [44], regulating host immunity [45], and maintaining metabolic health [46]. A recent study showed that the ratio of human to bacterial cells is almost 1:1 [47]. The major phylogenetic types within the digestive tract consist of Bacteroidetes (Porphytomonas, Prevotella), Firmicutes (Ruminococcus, Clostridium, and Eubacteria), Proteobacteria with minor groups of Actinobacteria (Bifidobacterium), Acidobacteria, Fusobacteria, and Verrumicrobia [48]. Firmicutes (Lactobacillus, Veillonella) and Proteobacteria (Helicobacter) are dominant in the proximal gut, whereas Firmicutes (Lachnospiraceae) and Bacteroidetes are observed in the colon [49,50]. The different types of gut microbiota are illustrated extensively in Figure 1. 


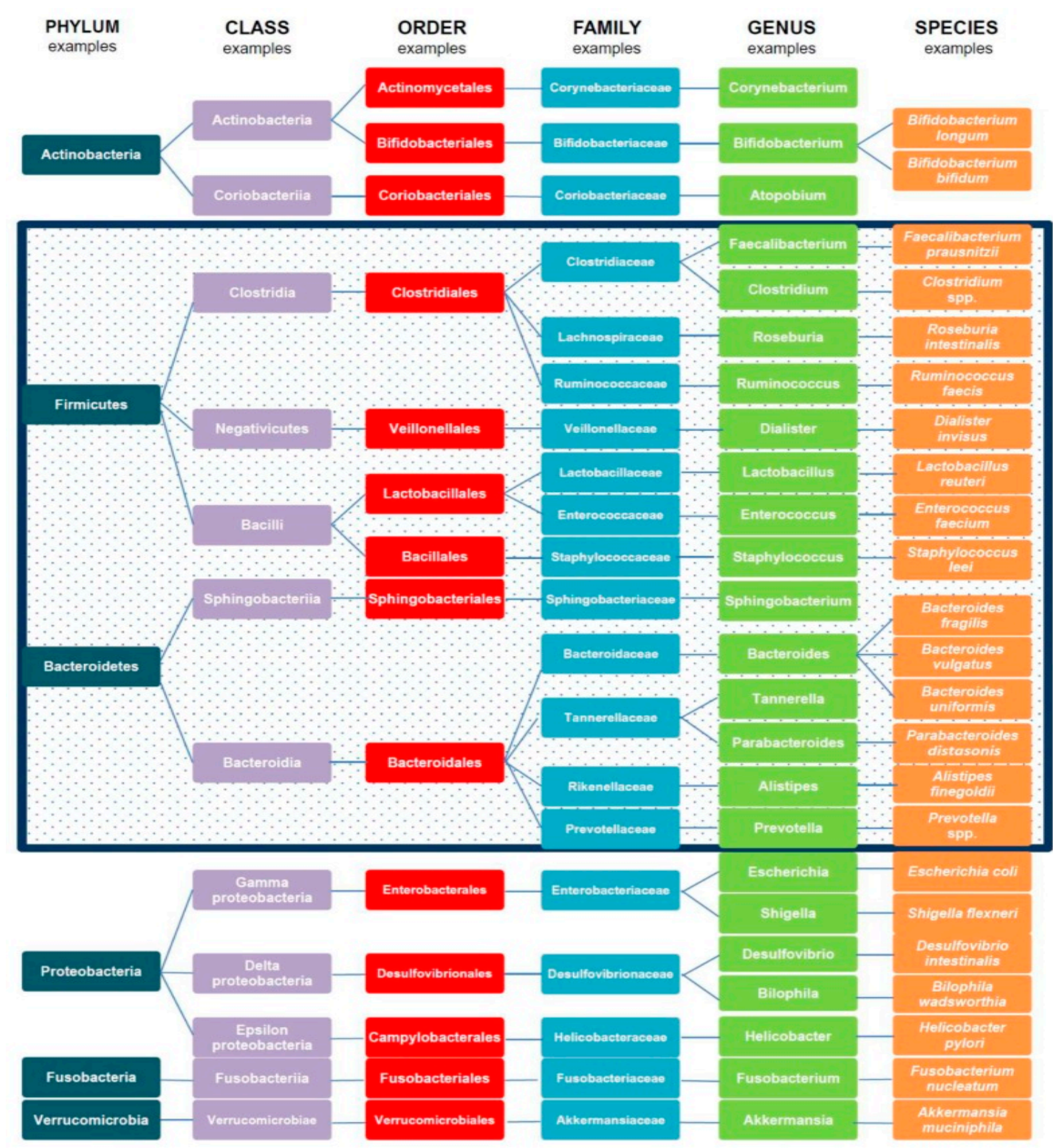

Figure 1. Bacterial types in the microbiome. Firmicutes and Bacteroidetes in the highlighted box represent approximately $90 \%$ of the total gut microbiota. Note. Adapted from [51].

Due to the antimicrobial effects of gastric and bile-acid secretion, a relatively low number of microbiota are present in the stomach and the proximal small intestine [52]. The composition and properties of the microbiome may depend on their occupation, as microbial populations at the mucosa surface and the lumen interact with the host immune system and the metabolic effects of food, respectively [53]. The gut microbiome has a critical role in the immune system through the prevention of pathogen colonization, stimulation of immunoglobulin A production, upregulation of anti-inflammatory cytokines, and $\mathrm{T}$ cell regulation [53]. For instance, Faecalibacterium prausnitzii and Bifidobacterium infantis may result in the production of the anti-inflammatory cytokine interleukin-10 and regulate $\mathrm{T}$ cell activation against the pathogen-stimulated NF-KB inflammatory pathway [54]. Other species may additionally induce lower inflammation levels by interleukin-17 expression, assisting host immunity in the protection of detrimental pathogens [55]. Furthermore, the gut microbiome is critical in the de novo synthesis of essential vitamins, such as vitamin B12, folate, vitamin $\mathrm{K}$, nicotinic acid, pyridoxine, and others [46], as well as bile acids [56]. Alteration of the co-metabolism 
of bile acids and vitamins has been associated with the development of metabolic diseases, such as obesity and type 2 diabetes [57]. A catalogue of the functional capacity of the human gut microbiome identified 9,879,896 genes wherein country-specific microbial signatures were found suggesting that gut microbiota composition is affected by multiple factors, such as host genetics, diet, health status, aging [58-60], and antibiotic administration [61].

\subsection{Gut Ecosystem and Metabolic Health}

The gut microbiota has a substantial impact on the regulation of metabolic processes, including nutrient and amino-acid metabolism [62,63]. Alterations in microbial composition may occur within $24 \mathrm{~h}$ following a change in dietary patterns [64], although greater changes may require a long-term adherence [65]. Microbial alterations are associated with multiple diseases, such as cancer, sarcopenia, obesity, and cardiovascular diseases [48,66,67]. An association between greater medication use with increased incidence of physical frailty and sarcopenia has been observed, which may be partly explained by the potential impact of polypharmacy on microbiota composition [68]. Indeed, distinct differences in the microbiota of healthy and frail older adults may partially explain the onset of frailty and sarcopenia [69] through effects on the mTOR signaling pathway - a major proponent of muscle protein synthesis (MPS) [70]. Moreover, dysfunctional musculoskeletal health has been suggested to be modulated by proinflammatory responses occurring in the microbiome [71]. Inflammatory responses associated with aging may induce microbial alterations influenced by pathogens, malnutrition, and lower overall lifestyle quality, leading to intestinal mucosa permeability $[25,72,73]$. Intestinal permeability initiates altered gut microbial composition (dysbiosis) and increases the levels of proinflammatory cytokines, such as interleukin-6 (IL-6) and tumor necrosis factor- $\alpha$ (TNF- $\alpha)$ [74,75]. Gut microbiota dysbiosis has a critical role in the gut-muscle axis through mitochondrial dysfunction, affecting skeletal-muscle metabolism further [76-79]. This may be perpetuated by reactive-oxygen-species (ROS) production in the elderly [80], which activate the NF- $\mathrm{kB}$ signaling pathway [81] - an activator of IL-6 and TNF- $\alpha$ release [76]. In obese groups, microbial diversity is significantly lower compared to lean population groups [82]. Microbial diversity including Bifidobacterium, Lactobacillus, Akkermansia, Fecalibacterium, Eubacterium, Roseburia, Ruminococcus, and Blautia species are considered beneficial for metabolic health in the elderly [83,84]. For instance, in leukemia-disordered mice, Lactobacillus-species restoration reduced muscle atrophy, which is also correlated with a decrease in various proinflammatory cytokines [85]. On the contrary, species, such as Clostridium, Enterobacter, Enterococcus, and Ruminococcus are associated with altered energy balance and greater risk of obesity [51]. Multiple studies have linked dietary patterns with changes in the gut ecosystem, displaying a distinct role of macronutrients and their impact on the gut microbiota environment $[64,86]$. However, the complexity in trying to understand the metabolic effects of gut microbiota and their relationship with detrimental health conditions is challenging [87]. Most studies have been performed in mice, which share $95 \%$ similar gut microbiota functionality with humans [88].

Moreover, alterations in gut microbiota composition are observed more commonly in people over the age of 65 compared to younger adults $[89,90]$. Higher microbial diversity from increased Bifidobacterium and Lactobacillus may promote more efficient nutrient absorption and amino-acid synthesis, whereas low microbial diversity is associated with excess nutrient uptake and storage and increased Firmicutes to Bacteroidetes ratio [91,92]. A greater abundance of Firmicutes relative to Bacteroides concentration is characterized in the microbiome of obese and insulin resistant humans and animals [93,94]. Interestingly, decreased Bifidobacterium levels are detected during aging, which is linked to increased circulating levels of lipopolysaccharide (LPS). Elevated levels of the endotoxin LPS are marked in obese and diabetic individuals, leading to gut microbiota dysbiosis, skeletal-muscle-insulin resistance and increased gut permeability [95-99]. LPS is a marker of endotoxemia, which promotes skeletal-muscle-insulin resistance by proinflammatory cytokine expression of TNF- $\alpha$, interleukin-1 (IL-1), interleukin-2 (IL-2), and IL-6 [100,101]. This highlights the potential of age-related decrements 
in gut microbiota (e.g., Bifidobacterium) to influence the development of sarcopenic obesity through decreased glucose tolerance in the skeletal muscle [95,100,102-104]. Furthermore, inflammatory cytokines induced during aging by enhanced LPS levels have demonstrated suppressed protein synthesis via muscle-protein synthesis and muscle-protein breakdown (MPS: MPB) imbalance, leading to reduced muscle mass and physical function [105-109]. In older adults, serum LPS and gene expression of its receptor, Toll-like receptor-4 (TLR4), is linked to lower insulin sensitivity compared to younger groups, showing that age-related LPS levels may increase the incidence of insulin resistance during aging $[103,110]$. Therefore, reductions in microbial diversity and functionality of the host may influence the functionality of several organs, including the skeletal muscle $[109,111,112]$. However, questions have been raised as to whether altered microbial diversity is caused by aging or if the microbiome is responsible for the consequences derived by aging $[113,114]$.

\section{Sarcopenic Obesity: A Case for Protein and Gut Microbiota}

\subsection{Dietary Protein and Gut Microbiota}

Protein is the dominant macronutrient in weight-loss strategies combatting sarcopenic obesity, given its appetite-suppressive effects [115] and anabolic effects on maintaining MPS above MPB [116]. The G protein-coupled receptors (GPCRs) located in the L- and G-cells of the colon and the small intestine, respectively, modulate glucagon-like peptide-1 (GLP-1) and peptide YY (PYY) secretion through amino-acid sensing, impeding the stimulation of food-intake regulatory effects occurring in the gut-brain axis [117-119]. In addition, satiation is further augmented by cholecystokinin (CCK) release, which is stimulated by protein consumption [120]. Studies have confirmed these effects compared to dietary carbohydrates and fats consumption [121], which may be attributed to the regulation of leptin and ghrelin secretion [122-125]. It is worth mentioning that, appetite-induced responses driven by signals between the gut microbiota and dietary protein may be determined by amino-acid composition [126] and, particularly, essential amino acids (i.e., leucine) $[127,128]$. Although dietary protein is established as a competent appetite regulator, its satiating and anabolic effects in older adults may be alleviated following lower protein diets [129]. The current RDA for protein at $0.8 \mathrm{~g} / \mathrm{kg} / \mathrm{day}$ may be insufficient for older adults due to their inability to absorb and utilize protein to the same extent compared to younger individuals $[106,108,130]$. Recommendations for leucine consumption-around 3-4 g per meal, which equates to $25-30 \mathrm{~g}$ of high quality protein and $1.0-1.6 \mathrm{~g} / \mathrm{kg} /$ day distributed into 3-4 daily meals-aim to promote greater MPS stimulation in older adults [131-134]. Dietary protein is the gut microbiota's primary source of amino acids, which can be used for protein synthesis and energy metabolism [135]. Currently, there is a controversy around the gut microbiota and high-protein diets in metabolic health and disease during aging. Microbiome changes are suggested to be engaged directly or indirectly in several mechanisms of age-related anabolic resistance, which may explain the necessity of greater protein intake in aging populations [136]. Anabolic resistance is associated with reduced gene expression in proteins involved in MPS, impaired protein absorption and digestion, loss of skeletal-muscle stem cells, and decreased amino-acid transportation in the skeletal muscle $[19,137,138]$. Furthermore, malnutrition and a sedentary lifestyle are proponents of anabolic resistance, increasing gradually with aging [116]. This raises questions on the impact gut microbiota may have on metabolic diseases, including the onset of sarcopenia and obesity [69].

Most protein is digested and absorbed efficiently in the small intestine by pancreatic enzymes and peptidases used by enterocytes, although approximately $10 \%$ of proteins that pass through the small intestine may not be completely digested [139]. Going to the large intestine for further proteolysis by the colonic microbiota, amino acids are not absorbed by the colonocytes as efficiently and some metabolites may be used for metabolic or waste products $[140,141]$. The transit time and microbiota concentration is greater in the large than the small intestine, with bacterial proteases and peptidases breaking down endogenous and dietary proteins to peptides and amino acids [142]. The undigested proteins and peptides that reach the colon influence gut microbiota production and composition, contributing 
to large amounts of indigestible products [143-145]. Regarding this, as protein consumption is increased, the amount of proteins reaching the colon is increasing correspondingly, leading to numerous and diverse bacterial metabolite production (e.g., hydrogen sulfide, branched-chain fatty acids (BCFAs), SCFAs, polyamines, ammonia, methane, aromatic compounds, nitric oxide, tyramine, tryptamine, phenethylamine, serotonin, histamine, and others) in the gastrointestinal tract $[141,146,147]$. Some of these metabolic products are detrimental for metabolic health and are associated with chronic inflammation and several diseases (e.g., inflammatory bowel disease, colorectal cancer). However, to date, there is no causal link in humans, taking into account the absence of long-term experimental trials on high protein diets and the gut microbiome and their multifaceted relationships [148,149].

Multiple human and animal studies have linked increased branched-chain amino acids (BCAAs) with insulin resistance and type 2 diabetes in obese groups [150-153]. However, increased SCFA consumption may alleviate the hyperglycemic responses that are occurring in obese and type 2 diabetics, characterized by elevated amino-acid concentrations [154]. In accordance, undigested amino acids by the colonic epithelium may be used by the host through BCFA and SCFA activity to regulate protein homeostasis and energy production by muscle cells $[141,142,155,156]$. BCAA deamination leading to BCFA production is a marker of colonic fermentation developed by protein consumption [147]. The conversion of BCAA valine, leucine, and isoleucine to isobutyrate, isovalerate, and 2-methylbutyrate, respectively [157], may contribute to approximately $5 \%$ of the total SCFA production [158]. This evidence indicates that the composition and concentration of amino acids may play a pivotal role in the proteolytic fermentation by the gut microbiota in the small intestine, which influences amino-acid homeostasis $[159,160]$. Therefore, it is recommended that high-protein diets should be carefully designed, considering the levels of protein fermentation by the gut microbiota and the amount of protein entering the large intestine $[139,145]$.

\subsection{Protein Sources, Amino Acids, and Gut Microbiota Species}

It is suggested that protein sources and amino-acid balance may influence gut microbial diversity. For instance, plant proteins are associated with greater Bifidobacterium, Roseburia, Ruminococcus bromii, Lactobacillus, and Roseburia content [161], as opposed to Bacteroides, Alistipes, Bilophila, and Clostridium perfrigens, found primarily in animal proteins [64,162]. A greater abundance of Bacteroidetes, Bifidobacterium, and decreased serum LPS levels compared to meat, dairy, and casein-protein consumption have been associated with soy-protein intake $[163,164]$. Furthermore, increased Bifidobacteria and Lactobacilli, which are linked to decreased diet-induced obesity and improved insulin sensitivity have been further supported by soy-protein consumption [165-167]. Likewise, increased bile-acid transformation, GLP-1 secretion, elevated Lactobacillus and Bifidobacterium levels, and reduced Firmicutes have been reported following soybean, mungbean, and buckwheat proteins $[168,169]$. In addition, Bifidobacteria-fermented whey and cheese protein have expressed decreased populations of Bacteroides fragilis and Clostridium perfingens, increased acetate production, and greater Lactobacillus and Bifidobacterium diversity [170-172]. Moreover, certain Lactobacillus and Bifidobacteria species have been associated with increased muscle strength, weight loss, and reduced obesogenic environments in humans and rodents [173-176]. This may be attributed to whey protein's abundance in Lactobacillus and Bifidobacteria, as reported in rodent studies [177-179]. Regarding this, higher Lactobacillus abundance has been demonstrated from white-meat-protein consumption, while supplementation of Lactobacillus plantarum has resulted in increased muscle mass in mice $[175,177,179-181]$. Examples of gut microbiota studies incorporating different protein types and sources, and their metabolic effects, are depicted in Table 1. 
Table 1. Metabolic effects of protein supplementation and gut microbiota interaction in selected animal and human studies.

\begin{tabular}{|c|c|c|c|}
\hline Study Type & Bacterial Type & Metabolic Effects & References \\
\hline Male mice supplemented with BCAAs & $\begin{array}{c}\text { Akkermansia } \uparrow \\
\text { Bifidobacterium } \uparrow \\
\text { Bacteroidetes } \uparrow \\
\text { Proteobacteria } \downarrow \\
\text { Actinobacteria } \downarrow \\
\text { Firmicutes } \downarrow\end{array}$ & $\begin{array}{l}\text { Weight change } \leftrightarrow \\
\text { LPS } \downarrow\end{array}$ & [182] \\
\hline Pigs supplemented with Leucine & $\begin{array}{l}\text { Actinobacteria } \uparrow \\
\text { Lactobacillus } \uparrow \\
\text { Firmicutes } \uparrow\end{array}$ & $\begin{array}{c}\text { Fat oxidation } \uparrow \\
\text { SCFAs } \uparrow \\
\text { LDL cholesterol } \downarrow \\
\text { Fat mass } \downarrow\end{array}$ & [183] \\
\hline Mice supplemented with Taurine & $\begin{array}{c}\text { Proteobacteria } \uparrow \\
\text { (Helicobacter) }\end{array}$ & $\begin{array}{c}\text { SCFAs } \uparrow \\
\text { LPS } \downarrow\end{array}$ & [184] \\
\hline $\begin{array}{l}\text { Mice fed with whey isolate vs. casein } \\
\text { for } 21 \text { weeks }\end{array}$ & $\begin{array}{l}\text { Lactobacillus } \uparrow \\
\text { Clostridium } \downarrow\end{array}$ & $\begin{array}{c}\text { Lean mass } \uparrow \\
\text { Leptin } \downarrow \\
\text { Fat mass } \downarrow\end{array}$ & [179] \\
\hline $\begin{array}{l}\text { Mice fed with buckwheat vs. casein } \\
\text { protein diets for } 6 \text { weeks }\end{array}$ & $\begin{array}{c}\text { Lactobacillus } \uparrow \\
\text { Bifidobacterium } \uparrow \\
\text { Enterococcus } \uparrow \\
\text { Clostridium } \uparrow \\
\text { Bacteroides } \downarrow\end{array}$ & $\begin{array}{c}\text { SCFAs } \uparrow \\
\text { TNF- } \alpha \downarrow \\
\text { IL- } 6 \downarrow \\
\text { LPS } \downarrow\end{array}$ & [169] \\
\hline $\begin{array}{l}\text { Mice fed with mungbean protein } \\
\text { isolate for } 4 \text { weeks }\end{array}$ & $\begin{array}{c}\text { Bacteroidetes } \uparrow \\
\text { Firmicutes } \downarrow\end{array}$ & $\begin{array}{c}\text { GLP-1 } \uparrow \\
\text { PYY } \\
\text { Insulin }\end{array}$ & [168] \\
\hline $\begin{array}{l}\text { Hamsters supplemented with soy vs. } \\
\text { milk protein }\end{array}$ & $\begin{array}{c}\text { Bifidobacteria } \uparrow \\
\text { Clostridiales } \uparrow \\
\text { Bacteroidetes } \downarrow \\
\text { Proteobacteria } \downarrow \\
\text { (Helicobacter) }\end{array}$ & $\begin{array}{l}\text { LDL cholesterol } \downarrow \\
\text { HbA1c } \downarrow\end{array}$ & [164] \\
\hline $\begin{array}{l}\text { Endurance athletes supplemented with } \\
\text { whey isolate }+ \text { beef hydrolysate for } \\
10 \text { weeks }\end{array}$ & $\begin{array}{c}\text { Bacteroidetes } \uparrow \\
\text { Bifidobacterium } \\
\text { longum } \downarrow \\
\text { Roseburia } \downarrow \\
\text { Blautia } \downarrow\end{array}$ & - & [185] \\
\hline $\begin{array}{l}\text { Healthy humans supplemented with } \\
\text { Bifidobacterium breve C50-fermented } \\
\text { whey protein for } 7 \text { days }\end{array}$ & $\begin{array}{c}\text { Bifidobacteria } \uparrow \\
\text { Bacteroides fragilis } \downarrow \\
\text { Clostridium } \\
\text { perfringens } \downarrow\end{array}$ & $\begin{array}{c}\text { B-galactosidase } \uparrow \\
\text { Nitroreductase } \downarrow \\
\beta \text {-glucuronidase } \downarrow\end{array}$ & [170] \\
\hline
\end{tabular}

$\downarrow$ indicates decrease; $\uparrow$ indicates increase; $\leftrightarrow$ indicates no change. SCFAs: Short-chain fatty acids, LDL: Low-density lipoprotein, TNF- $\alpha$ : Tumor necrosis factor alpha, IL-6: Interleukin-6, PYY: Peptide YY, HbA1c: Glycated hemoglobin.

Furthermore, greater SCFA content and reduced Proteobacteria (Helicobacter) have been found in mice supplemented with seafood protein, which is characterized by increased taurine levels $[184,186]$. Additionally, higher Bifidobacterium, Lactobacillus, and SCFA production have been observed by high pea-protein intake, which suppresses the secretion of inflammatory cytokines, IL-6 and TNF- $\alpha$, and improves interleukin-10 (IL-10) expression and glucose homeostasis [187-190]. Conversely, heterocyclic amines and glycan derived from red meat may promote inflammation in gut health due to higher concentration of Bacteroides and Fusobacterium and lower levels of Lactobacillus and Roseburia, which are also linked with lower anti-inflammatory responses and increased incidence of type 2 diabetes [191-193]. Accordingly, L-carnitine present in red meat can be metabolized to trimethylamine oxide (TMAO), which is associated with an increased incidence of atherosclerosis [194] and obesity [195]. This may not be compatible, however, with studies yielding higher circulating 
TMAO following consumption of seafood and fish products, known to be cardio-protective, compared with eggs and red meat proteins [196,197]. In addition, a high mixed whey-beef protein supplement for 70 days given in endurance athletes, reduced Roseburia, Bifidobacterium longum, and Blautia and increased Bacteroidetes species compared to the control group receiving maltodextrin [185]. However, in another study, high-protein beef supplementation in germ-free vs. unaltered microbiome mice depicted grip strength improvement in both groups [198], questioning the effects of high-protein beef administration in mice with different microbial composition. Likewise, the mice colonized with gut microbiota from older adults with increased functionality displayed enhanced muscle strength, exhibiting a greater abundance of the Prevotellaceae family compared to the lower-functionality older-adult donors [198]. Microbiota transplants from pathogen-free mice have also shown reduced skeletal-muscle atrophy and mitochondria dysfunction markers than germ-free mice; more notably increased serum choline levels and neuromuscular junction proteins, Rapsyn and Lrp4 [199]. Overall, white-meat protein (chicken, fish) demonstrates positive outcomes for the host vs. red-meat protein (beef, pork) due to increased abundance of Lactobacillus [200]. It is worth noting that, certain pro- and prebiotic products contain Bifidobacterium and Lactobacillus species for their regulatory effects on the microbiome, bone, and muscle health, which are crucial against frailty phenotypes in older individuals [201-203]. Interestingly, favorable microbial composition has been displayed by plant proteins compared to white meat and, to a greater extent, red meat proteins, partly due to a higher proportion of SCFA-producing bacteria. However, results should be treated with caution considering the lack of experimental human studies [204-206]. Moreover, the variety of amino acids from different protein types available to the intestinal bacteria may regulate whole-body amino acid metabolism and protein utilization [207]. Metabolism of serine, aspartame, and alanine are regulated in the small intestine by L-glutamine, while phenylalanine, tyrosine, and tryptophan are involved in species found in Clostridium bartlettii, Eubacterium hallii, and Bacteroides [208,209]. In addition, lysine, glutamate, glycine, ornithine, aspartame, and threonine may contribute to acetate metabolism, whereas lysine, glutamate, and threonine to butyrate synthesis $[63,141]$. This indicates that amino acids are crucial for SCFA synthesis showing great versatility regarding the production and synthesis of different SCFAs. Furthermore, delayed age-associated microbiota changes in mice have been observed by BCAA consumption, displaying a greater abundance of Bifidobacterium and Akkermansia [210], which improve glucose homeostasis and insulin sensitivity [182,211,212]. Although beneficial and deleterious effects from protein consumption have been identified, the health effects of amino acids on the metabolic human phenotype interfered with the gut microbiota that depend on protein digestibility and absorption are yet to be fully understood.

\subsection{Protein Utilization in the Gut: The Role of Dietary Fiber}

Short-chain fatty-acid production is primarily derived from non-digestible-carbohydrate (i.e., dietary fiber) consumption [213] during colonic bacterial fermentation [214]. These fermented products include acetate, propionate, and butyrate, approximately in a 60:20:20 ratio, respectively [215], and the two non-digestible carbohydrate categories are soluble (pectin, guar gum, psyllium, inulin) and insoluble fiber (cellulose, hemicellulose, lignin) [216]. The recommended intake for dietary fiber is deemed to be country-specific. For example, in the UK, the dietary target is settled at $30 \mathrm{~g} /$ day, while in Australia it is at $28 \mathrm{~g}$ and $38 \mathrm{~g}$ for women and men, respectively. However, in both countries, the majority of the population does not meet the suggested fiber intake [217,218]. Dietary fiber may induce an array of metabolic effects [219], including reduced systemic inflammation by regulating cytokine expression, primarily interleukin-18, improved fat oxidation and insulin sensitivity [220-223]. The emerging role of SCFAs on skeletal-muscle metabolism and function was recently reviewed [224]. In addition, increased leucine levels are correlated with enhanced butyrate and propionate concentrations in pigs, displaying a greater abundance of Actinobacteria species and body-fat loss [183]. This may indicate that the microbiome may play a pivotal role in mTOR activation and leucine metabolism in the intestinal epithelial cells, possessing a propitious role in metabolic health [86]. Likewise, amino acids, such as tryptophan, alanine, and phenylalanine may also impact satiety and gut motility through GLP-1, 
PYY, and serotonin modulation from the intestinal enteroendocrine L cells [225-231]. SCFAs may act as substrates in several tissues for GPCRs, stimulating GLP-1 and PYY release, delaying gastric emptying and reducing appetite and food intake [227,232,233]. Similarly, it has been shown that propionate attenuates reward-based eating behavior via striatal pathways [234], which are linked to hyperpalatable food consumption, known for its high-calorie content and association with obesogenic environments [235]. Hence, the potent anabolic effects and peripherally appetite-induced responses of SCFAs and amino acids, particularly BCAAs, could reduce the risk of anabolic resistance in parallel with greater adiposity, which are precursors of sarcopenic obesity.

Furthermore, the influence of protein fermentation in the gut is primarily regulated by substrate utilization and transit time. It is suggested that the ratio of carbohydrates and protein consumed impacts the protein utilized by the microbiome. Following a 2-week high-protein diet (1.5-2.2 $\mathrm{g} / \mathrm{kg} /$ day) in older women, microbial composition remained unaltered in the absence of added probiotic formulation [236]. The suppressed butyrate-producing populations of Roseburia and Anaerostipes were lower than the probiotic added groups and no changes were seen regarding Eubacterium and Ruminococcus, possibly due to the higher fiber intake of the plant-based products. Accordingly, a synbiotic-used probiotic component expressed increased Bifidobacterium and Lactobacillus during a weight-loss program containing a high-protein/low carbohydrate diet compared to the placebo group, indicating the potential requirement of probiotic supplementation for improved microbial richness [237]. Moreover, high-protein/low-carbohydrate diets in obese subjects showed reduced butyrate-producing bacteria and decreased levels of Roseburia and Eubacterium rectale, displaying a dose-response relationship, as carbohydrate intake was decreasing [148,238,239]. Likewise, decreased Eubacterium rectale and Bifidobacteria have been observed during weight-loss strategies in overweight and obese individuals in which further resistant-starch-carbohydrates reductions were common [240,241].

Altered microbial composition by increased Bacteroides and Dorea and reduced Faecalibacterium species have also been reported in elite race walkers following a $2.2 \mathrm{~g} / \mathrm{kg} / \mathrm{day}$ diet containing $<50 \mathrm{~g}$ carbohydrates, although their training and body composition status are confounding factors [242]. In animals, decreased butyrate-producing bacteria from Roseburia genera, Faecalibacterium, and Clostridium XIVa, as well as increased Firmicutes, have been confirmed by high-protein consumption as opposed to moderate protein intakes $[243,244]$. The bacterial and metabolic effects of high-protein and low-carbohydrate (low-CHO) diets in humans and animals are summarized in Table 2.

Table 2. Gut microbiota and metabolic alterations following increased protein and reduced carbohydrate diets.

\begin{tabular}{cccc}
\hline Study Type & Bacterial Type & Metabolic Effects & References \\
\hline $\begin{array}{c}\text { 2-week high-protein/low-CHO diet in } \\
\text { healthy older women (aged >65) }\end{array}$ & $\begin{array}{c}\text { Lactobacillus } \uparrow \\
\text { Lactococcus } \uparrow \\
\text { Streptococcus } \uparrow \\
\text { Roseburia } \downarrow \\
\text { Anaerostipes } \downarrow\end{array}$ & Fat-free mass $\uparrow$ & [236] \\
\hline $\begin{array}{c}\text { Hypocaloric high-protein/low-CHO } \\
\text { diet with Bifidobacterium and } \\
\text { lactobacillus synbiotic }\end{array}$ & $\begin{array}{c}\text { Bifidobacteria } \uparrow \\
\text { Lactobacilli } \uparrow\end{array}$ & $\begin{array}{c}\text { Body weight } \downarrow \\
\text { Fat mass } \downarrow \\
\text { Waist } \\
\text { Circumference } \downarrow \\
\text { HbA1c } \downarrow\end{array}$ & [237] \\
\hline $\begin{array}{c}\text { High-protein/low-CHO vs. medium to } \\
\text { high-CHO diet in obese humans }\end{array}$ & $\begin{array}{c}\text { Bifidobacteria } \downarrow \\
\text { Roseburia } \downarrow\end{array}$ & Butyrate $\downarrow$ & [239] \\
\hline $\begin{array}{c}\text { 8-week high-fat/low-CHO vs. } \\
\text { low-fat/high-CHO diet in overweight } \\
\text { and obese humans }\end{array}$ & Bifidobacteria $\downarrow$ & SCFAs $\downarrow$ & [238] \\
\hline
\end{tabular}


Table 2. Cont.

\begin{tabular}{|c|c|c|c|}
\hline Study Type & Bacterial Type & Metabolic Effects & References \\
\hline $\begin{array}{c}\text { Crossover 4-week } \\
\text { high-protein/low-CHO vs. } \\
\text { high-protein/medium-CHO diet in } \\
\text { obese humans }\end{array}$ & $\begin{array}{c}\text { Roseburia } \downarrow \\
\text { Eubacterium rectale } \downarrow\end{array}$ & $\begin{array}{c}\text { BCFAs } \uparrow \\
\text { Butyrate } \downarrow\end{array}$ & [148] \\
\hline $\begin{array}{l}\text { High-protein ( } 55 \% \text { vs. } 30 \% \text { vs. } 14 \%) \\
\text { isocaloric diets in C } 57 \mathrm{BL} / 6 \text { Dextran } \\
\text { Sodium Sulfate (DSS)-treated mice }\end{array}$ & $\begin{array}{c}\text { Proteobacteria } \uparrow \\
\text { Actinobacteria } \uparrow \\
\text { Bacteroidetes } \uparrow \\
\text { Clostridium XIVa } \downarrow \\
\text { Faecalibacterium } \downarrow \\
\text { Roseburia } \downarrow\end{array}$ & 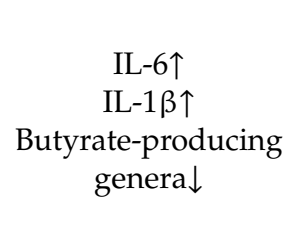 & [244] \\
\hline
\end{tabular}

Overall, complex carbohydrate availability may lower protein fermentation, leading to a greater number of nitrogenous substrates intended to promote muscle anabolism. Therefore, recommendations on the ratio and source of dietary protein [245] and carbohydrate consumption focusing on dietary fiber would be pivotal for skeletal-muscle and metabolic health through the impact of the metabolites generated in the large and small intestine [160].

\section{Conclusions}

The above sections illustrate the necessity of evaluating appropriate dietary components with the inclusion of both animal and plant-based food sources to optimize certain levels of gut microbiota species within high-protein diets. Regulating the quantity and source of food products may serve as a critical component for the control of protein and carbohydrate-fermenting bacteria, which could greatly influence various metabolic pathways. Given that different high-protein foods contain a varied micro- and macronutrient profile with notable distinctions among legumes, dairy, red and white meat, the microbial environment responsible for benefits and drawbacks in sarcopenic obesity cannot be accredited to a specific protein origin.

Consequently, the amount and source of protein combined with other lifestyle factors need to be defined in regards to microbial diversity, which further supports a personalized overall macronutrient approach considering individual variation in microbial composition. Gender, ethnicity, medical history, medication use, physical activity, genetics, local environment, and diet may all contribute significantly to different microbiota composition in older adults. Designing novel dietary patterns by examining these factors carefully in relation to specific microbial species may lead to a reduced incidence of obesity and improvements in skeletal-muscle-insulin sensitivity, as well as counteract sarcopenia and obesity during weight loss interventions using high-protein and fiber-rich diets. Therefore, biomarkers identifying dietary protein's digestive capacity could aid older groups in monitoring their optimal daily protein intake and would minimise inappropriate amino acids reaching the colon and provide greater caloric availability for increased consumption of other vital macronutrients, such as dietary fiber, to optimize gut microbial eubiosis. Furthermore, fortification of plant-based products with essential amino acids and the addition of host-protective bacteria in high-protein animal products (e.g., kefir) could provide optimal MPS synthesis and microbial diversity. However, the overall quality of foods and supplements, alongside their protein content should also be evaluated considering the gut microbial changes that may occur throughout food processing. Moreover, the lack of long-term experimental human trials, more effective gene-sequencing methods for bacterial identification, and microbial exploration in several organs of the gastrointestinal tract present challenges in predicting the appropriate timing during which microbiome testing should be performed to identify microbiome changes occurring over time. At present, more human studies investigating the microbiome of sarcopenic obese groups are warranted. Focusing on the establishment and promotion of novel dietary protein and fiber RDAs, 
and aiming for greater BCFA and SCFA abundance, respectively, could provide various metabolic benefits in sarcopenic and obese individuals before we move towards a more personalized dietary approach through advanced microbiome metabolomic techniques.

Author Contributions: K.P. conceived and wrote the initial draft of the manuscript; M.M.C., A.G., and D.S. reviewed and revised the manuscript. All authors have read and agreed to the published version of the manuscript.

Funding: This review received no external funding.

Conflicts of Interest: The authors declare no conflict of interest.

\section{References}

1. Lo, J.H.; Kin, P.U.; Yiu, T.; Ong, M.T.; Lee, W.Y. Sarcopenia: Current treatments and new regenerative therapeutic approaches. J. Orthop. Transl. 2020, 23, 38-52. [CrossRef] [PubMed]

2. Sigit, F.S.; Tahapary, D.L.; Trompet, S.; Sartono, E.; van Dijk, K.W.; Rosendaal, F.R.; de Mutsert, R. The prevalence of metabolic syndrome and its association with body fat distribution in middle-aged individuals from Indonesia and the Netherlands: A cross-sectional analysis of two population-based studies. Diabetol. Metab. Syndr. 2020, 12, 2. [CrossRef] [PubMed]

3. Paley, C.A.; Johnson, M.I. Abdominal obesity and metabolic syndrome: Exercise as medicine? BMC Sports Sci. Med. Rehabil. 2018, 10, 7. [CrossRef] [PubMed]

4. Rubio-Ruiz, M.E.; Guarner-Lans, V.; Perez-Torres, I.; Soto, M.E. Mechanisms underlying metabolic syndrome-related sarcopenia and possible therapeutic measures. Int. J. Mol. Sci. 2019, 20, 647. [CrossRef]

5. Wall, B.T.; Dirks, M.L.; van Loon, L.J. Skeletal muscle atrophy during short-term disuse: Implications for age-related sarcopenia. Ageing Res. Rev. 2013, 12, 898-906. [CrossRef] [PubMed]

6. Deschenes, M.R. Effects of aging on muscle fibre type and size. Sports Med. 2004, 34, 809-824. [CrossRef]

7. Cesari, M.; Landi, F.; Vellas, B.; Bernabei, R.; Marzetti, E. Sarcopenia and physical frailty: Two sides of the same coin. Front. Aging Neurosci. 2014, 6, 192. [CrossRef]

8. Scott, D.; Johansson, J.; McMillan, L.B.; Ebeling, P.R.; Nordstrom, P.; Nordstrom, A. Associations of sarcopenia and its components with bone structure and incident falls in Swedish older adults. Calcif. Tissue Int. 2019, 105, 26-36. [CrossRef]

9. Vitale, G.; Cesari, M.; Mari, D. Aging of the endocrine system and its potential impact on sarcopenia. Eur. J. Intern. Med. 2016, 35, 10-15. [CrossRef]

10. Marzetti, E.; Picca, A.; Marini, F.; Biancolillo, A.; Coelho-Junior, H.J.; Gervasoni, J.; Bossola, M.; Cesari, M.; Onder, G.; Landi, F.; et al. Inflammatory signatures in older persons with physical frailty and sarcopenia: The frailty "cytokinome" at its core. Exp. Gerontol. 2019, 122, 129-138. [CrossRef]

11. Cruz-Jentoft, A.J.; Bahat, G.; Bauer, J.; Boirie, Y.; Bruyere, O.; Cederholm, T.; Cooper, C.; Landi, F.; Rolland, Y.; Sayer, A.A.; et al. Sarcopenia: Revised European consensus on definition and diagnosis. Age Ageing 2019, 48, 16-31. [CrossRef] [PubMed]

12. Santilli, V.; Bernetti, A.; Mangone, M.; Paoloni, M. Clinical definition of sarcopenia. Clin. Cases Miner. Bone Metab. 2014, 11, 177-180. [CrossRef] [PubMed]

13. Tremmel, M.; Gerdtham, U.G.; Nilsson, P.M.; Saha, S. Economic burden of obesity: A systematic literature review. Int. J. Environ. Res. Public Health 2017, 14, 435. [CrossRef] [PubMed]

14. Schwartz, M.W.; Seeley, R.J.; Zeltser, L.M.; Drewnowski, A.; Ravussin, E.; Redman, L.M.; Leibel, R.L. Obesity pathogenesis: An endocrine society scientific statement. Endocr. Rev. 2017, 38, 267-296. [CrossRef] [PubMed]

15. Garg, S.K.; Maurer, H.; Reed, K.; Selagamsetty, R. Diabetes and cancer: Two diseases with obesity as a common risk factor. Diabetes Obes. Metab. 2014, 16, 97-110. [CrossRef] [PubMed]

16. Lean, M.E.H.; Morrison, C.E. Waist circumference as a measure for indicating need for weight management. Br. Med. J. 1995, 311, 158-161. [CrossRef]

17. Flegal, K.M.; Kruszon-Moran, D.; Carroll, M.D.; Fryar, C.D.; Ogden, C.L. Trends in obesity among adults in the United States, 2005 to 2014. JAMA 2016, 315, 2284-2291. [CrossRef]

18. Ng, M.; Fleming, T.; Robinson, M.; Thomson, B.; Graetz, N.; Margono, C.; Mullany, E.C.; Biryukov, S.; Abbafati, C.; Abera, S.F.; et al. Global, regional, and national prevalence of overweight and obesity in children and adults during 1980-2013: A systematic analysis for the Global Burden of Disease Study 2013. Lancet 2014, 384, 766-781. [CrossRef] 
19. Ticinesi, A.; Nouvenne, A.; Cerundolo, N.; Catania, P.; Prati, B.; Tana, C.; Meschi, T. Gut microbiota, muscle mass and function in aging: A focus on physical frailty and sarcopenia. Nutrients 2019, 11, 1633. [CrossRef]

20. Enoki, Y.; Watanabe, H.; Arake, R.; Sugimoto, R.; Imafuku, T.; Tominaga, Y.; Ishima, Y.; Kotani, S.; Nakajima, M.; Tanaka, M.; et al. Indoxyl sulfate potentiates skeletal muscle atrophy by inducing the oxidative stress-mediated expression of myostatin and atrogin-1. Sci. Rep. 2016, 6, 32084. [CrossRef]

21. Van de Wouw, M.; Schellekens, H.; Dinan, T.G.; Cryan, J.F. Microbiota-gut-brain axis: Modulator of host metabolism and appetite. J. Nutr. 2017, 147, 727-745. [CrossRef] [PubMed]

22. Oliphant, K.; Allen-Vercoe, E. Macronutrient metabolism by the human gut microbiome: Major fermentation by-products and their impact on host health. Microbiome 2019, 7, 91. [CrossRef] [PubMed]

23. Dalile, B.; Van Oudenhove, L.; Vervliet, B.; Verbeke, K. The role of short-chain fatty acids in microbiota-gut-brain communication. Nat. Rev. Gastroenterol. Hepatol. 2019, 16, 461-478. [CrossRef] [PubMed]

24. Muscariello, E.; Nasti, G.; Siervo, M.; Di Maro, M.; Lapi, D.; D’Addio, G.; Colantuoni, A. Dietary protein intake in sarcopenic obese older women. Clin. Interv. Aging 2016, 11, 133-140. [CrossRef] [PubMed]

25. Diether, N.E.; Willing, B.P. Microbial fermentation of dietary protein: An important factor in Diet(-)Microbe(-)Host Interaction. Microorganisms 2019, 7, 19. [CrossRef] [PubMed]

26. Kim, T.N.; Park, M.S.; Yang, S.J.; Yoo, H.J.; Kang, H.J.; Song, W.; Seo, J.A.; Kim, S.G.; Kim, N.H.; Baik, S.H.; et al. Prevalence and determinant factors of sarcopenia in patients with type 2 diabetes: The Korean Sarcopenic Obesity Study (KSOS). Diabetes Care 2010, 33, 1497-1499. [CrossRef]

27. Son, J.W.; Lee, S.S.; Kim, S.R.; Yoo, S.J.; Cha, B.Y.; Son, H.Y.; Cho, N.H. Low muscle mass and risk of type 2 diabetes in middle-aged and older adults: Findings from the KoGES. Diabetologia 2017, 60, 865-872. [CrossRef]

28. Mesinovic, J.; Zengin, A.; De Courten, B.; Ebeling, P.R.; Scott, D. Sarcopenia and type 2 diabetes mellitus: A bidirectional relationship. Diabetes Metab. Syndr. Obes. 2019, 12, 1057-1072. [CrossRef]

29. Lee, C.G.; Boyko, E.J.; Strotmeyer, E.S.; Lewis, C.E.; Cawthon, P.M.; Hoffman, A.R.; Everson-Rose, S.A.; Barrett-Connor, E.; Orwoll, E.S.; Osteoporotic Fractures in Men Study Research Group. Association between insulin resistance and lean mass loss and fat mass gain in older men without diabetes mellitus. J. Am. Geriatr. Soc. 2011, 59, 1217-1224. [CrossRef]

30. Shao, A.; Campbell, W.W.; Chen, C.Y.O.; Mittendorfer, B.; Rivas, D.A.; Griffiths, J.C. The emerging global phenomenon of sarcopenic obesity: Role of functional foods; A conference report. J. Funct. Foods 2017, 33, 244-250. [CrossRef]

31. Batsis, J.A.; Villareal, D.T. Sarcopenic obesity in older adults: Aetiology, epidemiology and treatment strategies. Nat. Rev. Endocrinol. 2018, 14, 513-537. [CrossRef] [PubMed]

32. Crow, R.S.; Lohman, M.C.; Titus, A.J.; Cook, S.B.; Bruce, M.L.; Mackenzie, T.A.; Bartels, S.J.; Batsis, J.A. Association of obesity and frailty in older adults: NHANES 1999-2004. J. Nutr. Health Aging 2019, 23, 138-144. [CrossRef] [PubMed]

33. Zhang, X.; Wang, C.; Dou, Q.; Zhang, W.; Yang, Y.; Xie, X. Sarcopenia as a predictor of all-cause mortality among older nursing home residents: A systematic review and meta-analysis. BMJ Open 2018, 8, e021252. [CrossRef] [PubMed]

34. Choi, K.M. Sarcopenia and sarcopenic obesity. Korean J. Intern. Med. 2016, 31, 1054-1060. [CrossRef] [PubMed]

35. Inglis, J.E.; Ilich, J.Z. The microbiome and osteosarcopenic obesity in older individuals in long-term care facilities. Curr. Osteoporos. Rep. 2015, 13, 358-362. [CrossRef]

36. Scott, D.; Shore-Lorenti, C.; McMillan, L.; Mesinovic, J.; Clark, R.A.; Hayes, A.; Sanders, K.M.; Duque, G.; Ebeling, P.R. Associations of components of sarcopenic obesity with bone health and balance in older adults. Arch. Gerontol. Geriatr. 2018, 75, 125-131. [CrossRef]

37. Scott, D.; Chandrasekara, S.D.; Laslett, L.L.; Cicuttini, F.; Ebeling, P.R.; Jones, G. Associations of sarcopenic obesity and dynapenic obesity with bone mineral density and incident fractures over 5-10 years in community-dwelling older adults. Calcif. Tissue Int. 2016, 99, 30-42. [CrossRef]

38. Roh, E.; Choi, K.M. Health consequences of sarcopenic obesity: A narrative review. Front. Endocrinol. (Lausanne) 2020, 11, 332. [CrossRef]

39. Orwoll, E.S.; Peters, K.E.; Hellerstein, M.; Cummings, S.R.; Evans, W.J.; Cawthon, P.M. The importance of muscle versus fat mass in sarcopenic obesity: A re-evaluation Using D3-Creatine muscle mass versus DXA lean mass measurements. J. Gerontol. A Biol. Sci. Med. Sci. 2020, 75, 1362-1368. [CrossRef] 
40. Yeung, S.S.Y.; Reijnierse, E.M.; Pham, V.K.; Trappenburg, M.C.; Lim, W.K.; Meskers, C.G.M.; Maier, A.B. Sarcopenia and its association with falls and fractures in older adults: A systematic review and meta-analysis. J. Cachexia Sarcopenia Muscle 2019, 10, 485-500. [CrossRef]

41. Landi, F.; Calvani, R.; Cesari, M.; Tosato, M.; Martone, A.M.; Ortolani, E.; Savera, G.; Salini, S.; Sisto, A.; Picca, A.; et al. Sarcopenia: An overview on current definitions, diagnosis and treatment. Curr. Protein Pept. Sci. 2018, 19, 633-638. [CrossRef] [PubMed]

42. Tremaroli, V.; Backhed, F. Functional interactions between the gut microbiota and host metabolism. Nature 2012, 489, 242-249. [CrossRef] [PubMed]

43. Harsch, I.A.; Konturek, P.C. The role of gut microbiota in obesity and type 2 and type 1 diabetes mellitus: New insights into "old" diseases. Med. Sci. (Basel) 2018, 6, 32. [CrossRef] [PubMed]

44. Natividad, J.M.; Verdu, E.F. Modulation of intestinal barrier by intestinal microbiota: Pathological and therapeutic implications. Pharmacol. Res. 2013, 69, 42-51. [CrossRef]

45. Gensollen, T.I.; Kasper, D.L.; Blumberg, R.S. How colonization by microbiota in early life shapes the immune system. Science 2016, 352, 539-544. [CrossRef]

46. LeBlanc, J.G.; Milani, C.; de Giori, G.S.; Sesma, F.; van Sinderen, D.; Ventura, M. Bacteria as vitamin suppliers to their host: A gut microbiota perspective. Curr. Opin. Biotechnol. 2013, 24, 160-168. [CrossRef]

47. Sender, R.; Fuchs, S.; Milo, R. Revised estimates for the number of human and bacteria cells in the body. PLoS Biol. 2016, 14, e1002533. [CrossRef]

48. Ley, R.E.; Peterson, D.A.; Gordon, J.I. Ecological and evolutionary forces shaping microbial diversity in the human intestine. Cell 2006, 124, 837-848. [CrossRef]

49. Sekirov, I.; Russell, S.L.; Antunes, L.C.; Finlay, B.B. Gut microbiota in health and disease. Physiol. Rev. 2010, 90, 859-904. [CrossRef]

50. Dieterich, W.; Schink, M.; Zopf, Y. Microbiota in the gastrointestinal tract. Med. Sci. (Basel) 2018, 6, 116. [CrossRef]

51. Rinninella, E.; Raoul, P.; Cintoni, M.; Franceschi, F.; Miggiano, G.A.D.; Gasbarrini, A.; Mele, M.C. What is the healthy gut microbiota composition? A changing ecosystem across age, environment, diet, and diseases. Microorganisms 2019, 7, 14. [CrossRef] [PubMed]

52. O'Hara, A.M.; Shanahan, F. The gut flora as a forgotten organ. EMBO Rep. 2006, 7, 688-693. [CrossRef] [PubMed]

53. Quigley, E.M. Gut bacteria in health and disease. Gastroenterol. Hepatol. 2013, 9, 560-569.

54. O'Mahony, C.; Scully, P.; O’Mahony, D.; Murphy, S.; O’Brien, F.; Lyons, A.; Sherlock, G.; MacSharry, J.; Kiely, B.; Shanahan, F.; et al. Commensal-induced regulatory $\mathrm{T}$ cells mediate protection against pathogen-stimulated NF-kappaB activation. PLoS Pathog. 2008, 4, e1000112. [CrossRef]

55. Pagnini, C.; Saeed, R.; Bamias, G.; Arseneau, K.O.; Pizarro, T.T.; Cominelli, F. Probiotics promote gut health through stimulation of epithelial innate immunity. Proc. Natl. Acad. Sci. USA 2010, 107, 454-459. [CrossRef]

56. Staley, C.; Weingarden, A.R.; Khoruts, A.; Sadowsky, M.J. Interaction of gut microbiota with bile acid metabolism and its influence on disease states. Appl. Microbiol. Biotechnol. 2017, 101, 47-64. [CrossRef]

57. Palau-Rodriguez, M.; Tulipani, S.; Isabel Queipo-Ortuno, M.; Urpi-Sarda, M.; Tinahones, F.J.; Andres-Lacueva, C. Metabolomic insights into the intricate gut microbial-host interaction in the development of obesity and type 2 diabetes. Front. Microbiol. 2015, 6, 1151. [CrossRef]

58. O'Toole, P.W.; Claesson, M.J. Gut microbiota: Changes throughout the lifespan from infancy to elderly. Int. Dairy J. 2010, 20, 281-291. [CrossRef]

59. Claesson, M.J.; Jeffery, I.B.; Conde, S.; Power, S.E.; O'Connor, E.M.; Cusack, S.; Harris, H.M.; Coakley, M.; Lakshminarayanan, B.; O'Sullivan, O.; et al. Gut microbiota composition correlates with diet and health in the elderly. Nature 2012, 488, 178-184. [CrossRef]

60. Li, J.; Jia, H.; Cai, X.; Zhong, H.; Feng, Q.; Sunagawa, S.; Arumugam, M.; Kultima, J.R.; Prifti, E.; Nielsen, T.; et al. An integrated catalog of reference genes in the human gut microbiome. Nat. Biotechnol. 2014, 32, 834-841. [CrossRef]

61. Robinson, C.J.; Young, V.B. Antibiotic administration alters the community structure of the gastrointestinal micobiota. Gut Microbes 2010, 1, 279-284. [CrossRef] [PubMed]

62. Dai, Z.W.; Zhu, W. Amino acid metabolism in intestinal bacteria: Links between gut ecology and host health. Front. Biosci. 2011, 16, 1768-1786. [CrossRef] [PubMed] 
63. Neis, E.P.; Dejong, C.H.; Rensen, S.S. The role of microbial amino acid metabolism in host metabolism. Nutrients 2015, 7, 2930-2946. [CrossRef] [PubMed]

64. David, L.A.; Maurice, C.F.; Carmody, R.N.; Gootenberg, D.B.; Button, J.E.; Wolfe, B.E.; Ling, A.V.; Devlin, A.S.; Varma, Y.; Fischbach, M.A.; et al. Diet rapidly and reproducibly alters the human gut microbiome. Nature 2014, 505, 559-563. [CrossRef]

65. Faith, J.J.; Guruge, J.L.; Charbonneau, M.; Subramanian, S.; Seedorf, H.; Goodman, A.L.; Clemente, J.C.; Knight, R.; Heath, A.C.; Leibel, R.L.; et al. The long-term stability of the human gut microbiota. Science 2013, 341, 1237439. [CrossRef]

66. Turnbaugh, P.J.; Ley, R.E.; Mahowald, M.A.; Magrini, V.; Mardis, E.R.; Gordon, J.I. An obesity-associated gut microbiome with increased capacity for energy harvest. Nature 2006, 444, 1027-1031. [CrossRef]

67. Harris, V.C.; Haak, B.W.; van Hensbroek, M.B.; Wiersinga, W.J. The intestinal microbiome in infectious diseases: The clinical relevance of a rapidly emerging field. Open Forum Infect. Dis. 2017, 4, ofx144. [CrossRef]

68. Ticinesi, A.; Milani, C.; Lauretani, F.; Nouvenne, A.; Mancabelli, L.; Lugli, G.A.; Turroni, F.; Duranti, S.; Mangifesta, M.; Viappiani, A.; et al. Gut microbiota composition is associated with polypharmacy in elderly hospitalized patients. Sci. Rep. 2017, 7, 11102. [CrossRef]

69. Casati, M.; Ferri, E.; Azzolino, D.; Cesari, M.; Arosio, B. Gut microbiota and physical frailty through the mediation of sarcopenia. Exp. Gerontol. 2019, 124, 110639. [CrossRef]

70. Lustgarten, M.S. The role of the gut microbiome on skeletal muscle mass and physical function: 2019 update. Front. Physiol. 2019, 10, 1435. [CrossRef]

71. Steves, C.J.; Bird, S.; Williams, F.M.; Spector, T.D. The microbiome and musculoskeletal conditions of aging: A review of evidence for impact and potential therapeutics. J. Bone Miner. Res. 2016, 31, 261-269. [CrossRef] [PubMed]

72. Hashimoto, T.; Perlot, T.; Rehman, A.; Trichereau, J.; Ishiguro, H.; Paolino, M.; Sigl, V.; Hanada, T.; Hanada, R.; Lipinski, S.; et al. ACE2 links amino acid malnutrition to microbial ecology and intestinal inflammation. Nature 2012, 487, 477-481. [CrossRef]

73. Ticinesi, A.; Lauretani, F.; Milani, C.; Nouvenne, A.; Tana, C.; Del Rio, D.; Maggio, M.; Ventura, M.; Meschi, T. Aging gut microbiota at the cross-road between nutrition, physical frailty, and sarcopenia: Is there a gut-muscle axis? Nutrients 2017, 9, 1303. [CrossRef] [PubMed]

74. Qi, Y.; Goel, R.; Kim, S.; Richards, E.M.; Carter, C.S.; Pepine, C.J.; Raizada, M.K.; Buford, T.W. Intestinal permeability biomarker zonulin is elevated in healthy aging. J. Am. Med. Dir. Assoc. 2017, 18, 810.e811-810.e814. [CrossRef] [PubMed]

75. Sovran, B.; Hugenholtz, F.; Elderman, M.; Van Beek, A.A.; Graversen, K.; Huijskes, M.; Boekschoten, M.V.; Savelkoul, H.F.J.; De Vos, P.; Dekker, J.; et al. Age-associated impairment of the mucus barrier function is associated with profound changes in microbiota and immunity. Sci. Rep. 2019, 9, 1437. [CrossRef] [PubMed]

76. Sakuma, K.; Yamaguchi, A. Sarcopenic obesity and endocrinal adaptation with age. Int. J. Endocrinol. 2013, 2013, 204164. [CrossRef]

77. Zhou, J.; Liu, B.; Liang, C.; Li, Y.; Song, Y.H. Cytokine signaling in skeletal muscle wasting. Trends Endocrinol. Metab. 2016, 27, 335-347. [CrossRef]

78. Marzetti, E.; Lorenzi, M.; Landi, F.; Picca, A.; Rosa, F.; Tanganelli, F.; Galli, M.; Doglietto, G.B.; Pacelli, F.; Cesari, M.; et al. Altered mitochondrial quality control signaling in muscle of old gastric cancer patients with cachexia. Exp. Gerontol. 2017, 87, 92-99. [CrossRef]

79. Picca, A.; Fanelli, F.; Calvani, R.; Mule, G.; Pesce, V.; Sisto, A.; Pantanelli, C.; Bernabei, R.; Landi, F.; Marzetti, E. Gut dysbiosis and muscle aging: Searching for novel targets against sarcopenia. Mediators Inflamm. 2018, 2018, 7026198. [CrossRef]

80. Meng, S.J.; Yu, L.J. Oxidative stress, molecular inflammation and sarcopenia. Int. J. Mol. Sci. 2010, 11, 1509-1526. [CrossRef]

81. Chung, H.Y.; Cesari, M.; Anton, S.; Marzetti, E.; Giovannini, S.; Seo, A.Y.; Carter, C.; Yu, B.P.; Leeuwenburgh, C. Molecular inflammation: underpinnings of aging and age-related diseases. Ageing Res. Rev. 2009, 8, 18-30. [CrossRef] [PubMed]

82. Sainsbury, A.; Zhang, L. Role of the arcuate nucleus of the hypothalamus in regulation of body weight during energy deficit. Mol. Cell. Endocrinol. 2010, 316, 109-119. [CrossRef] [PubMed] 
83. Hiippala, K.; Jouhten, H.; Ronkainen, A.; Hartikainen, A.; Kainulainen, V.; Jalanka, J.; Satokari, R. The potential of gut commensals in reinforcing intestinal barrier function and alleviating inflammation. Nutrients 2018, 10, 988. [CrossRef] [PubMed]

84. Cancello, R.; Turroni, S.; Rampelli, S.; Cattaldo, S.; Candela, M.; Cattani, L.; Mai, S.; Vietti, R.; Scacchi, M.; Brigidi, P.; et al. Effect of short-term dietary intervention and probiotic mix supplementation on the gut microbiota of elderly obese women. Nutrients 2019, 11, 3011. [CrossRef] [PubMed]

85. Bindels, L.B.; Beck, R.; Schakman, O.; Martin, J.C.; De Backer, F.; Sohet, F.M.; Dewulf, E.M.; Pachikian, B.D.; Neyrinck, A.M.; Thissen, J.P.; et al. Restoring specific lactobacilli levels decreases inflammation and muscle atrophy markers in an acute leukemia mouse model. PLOS ONE 2012, 7, e37971. [CrossRef]

86. Yang, Q.; Liang, Q.; Balakrishnan, B.; Belobrajdic, D.P.; Feng, Q.J.; Zhang, W. Role of dietary nutrients in the modulation of gut microbiota: A narrative review. Nutrients 2020, 12, 381. [CrossRef]

87. McFall-Ngai, M.; Hadfield, M.G.; Bosch, T.C.; Carey, H.V.; Domazet-Loso, T.; Douglas, A.E.; Dubilier, N.; Eberl, G.; Fukami, T.; Gilbert, S.F.; et al. Animals in a bacterial world, a new imperative for the life sciences. Proc. Natl. Acad. Sci. USA 2013, 110, 3229-3236. [CrossRef]

88. Xiao, L.; Feng, Q.; Liang, S.; Sonne, S.B.; Xia, Z.; Qiu, X.; Li, X.; Long, H.; Zhang, J.; Zhang, D.; et al. A catalog of the mouse gut metagenome. Nat. Biotechnol. 2015, 33, 1103-1108. [CrossRef]

89. Zapata, H.J.; Quagliarello, V.J. The microbiota and microbiome in aging: Potential implications in health and age-related diseases. J. Am. Geriatr. Soc. 2015, 63, 776-781. [CrossRef]

90. O'Toole, P.W.; Jeffery, I.B. Microbiome-health interactions in older people. Cell. Mol. Life Sci. 2018, 75, 119-128. [CrossRef]

91. Le Chatelier, E.; Nielsen, T.; Qin, J.; Prifti, E.; Hildebrand, F.; Falony, G.; Almeida, M.; Arumugam, M.; Batto, J.M.; Kennedy, S.; et al. Richness of human gut microbiome correlates with metabolic markers. Nature 2013, 500, 541-546. [CrossRef] [PubMed]

92. Riva, A.; Borgo, F.; Lassandro, C.; Verduci, E.; Morace, G.; Borghi, E.; Berry, D. Pediatric obesity is associated with an altered gut microbiota and discordant shifts in Firmicutes populations. Dig. Liver Dis. 2016, 48. [CrossRef]

93. Tilg, H.; Kaser, A. Gut microbiome, obesity, and metabolic dysfunction. J. Clin. Investig. 2011, 121, $2126-2132$. [CrossRef] [PubMed]

94. Han, G.G.; Lee, J.Y.; Jin, G.D.; Park, J.; Choi, Y.H.; Chae, B.J.; Kim, E.B.; Choi, Y.J. Evaluating the association between body weight and the intestinal microbiota of weaned piglets via $16 \mathrm{~S}$ rRNA sequencing. Vet. Microbiol. 2016, 196, 55-62. [CrossRef]

95. Cani, P.D.; Neyrinck, A.M.; Fava, F.; Knauf, C.; Burcelin, R.G.; Tuohy, K.M.; Gibson, G.R.; Delzenne, N.M. Selective increases of bifidobacteria in gut microflora improve high-fat-diet-induced diabetes in mice through a mechanism associated with endotoxaemia. Diabetologia 2007, 50, 2374-2383. [CrossRef]

96. Creely, S.J.; McTernan, P.G.; Kusminski, C.M.; Fisher, F.M.; Da Silva, N.F.; Khanolkar, M.; Evans, M.; Harte, A.L.; Kumar, S. Lipopolysaccharide activates an innate immune system response in human adipose tissue in obesity and type 2 diabetes. Am. J. Physiol. Endocrinol. Metab. 2007, 292, E740-E747. [CrossRef]

97. Dasu, M.R.; Devaraj, S.; Park, S.; Jialal, I. Increased toll-like receptor (TLR) activation and TLR ligands in recently diagnosed type 2 diabetic subjects. Diabetes Care 2010, 33, 861-868. [CrossRef]

98. Manco, M.; Putignani, L.; Bottazzo, G.F. Gut microbiota, lipopolysaccharides, and innate immunity in the pathogenesis of obesity and cardiovascular risk. Endocr. Rev. 2010, 31, 817-844. [CrossRef]

99. Morales, M.G.; Olguin, H.; Di Capua, G.; Brandan, E.; Simon, F.; Cabello-Verrugio, C. Endotoxin-induced skeletal muscle wasting is prevented by angiotensin-(1-7) through a p38 MAPK-dependent mechanism. Clin. Sci. (Lond.) 2015, 129, 461-476. [CrossRef]

100. Liang, H.; Hussey, S.E.; Sanchez-Avila, A.; Tantiwong, P.; Musi, N. Effect of lipopolysaccharide on inflammation and insulin action in human muscle. PLoS ONE 2013, 8, e63983. [CrossRef]

101. House, L.M., 2nd; Morris, R.T.; Barnes, T.M.; Lantier, L.; Cyphert, T.J.; McGuinness, O.P.; Otero, Y.F. Tissue inflammation and nitric oxide-mediated alterations in cardiovascular function are major determinants of endotoxin-induced insulin resistance. Cardiovasc. Diabetol. 2015, 14, 56. [CrossRef] [PubMed]

102. Reyna, S.M.; Ghosh, S.; Tantiwong, P.; Meka, C.S.; Eagan, P.; Jenkinson, C.P.; Cersosimo, E.; Defronzo, R.A.; Coletta, D.K.; Sriwijitkamol, A.; et al. Elevated toll-like receptor 4 expression and signaling in muscle from insulin-resistant subjects. Diabetes 2008, 57, 2595-2602. [CrossRef] [PubMed] 
103. Ghosh, S.; Lertwattanarak, R.; de Jesus Garduno, J.; Galeana, J.J.; Li, J.; Zamarripa, F.; Lancaster, J.L.; Mohan, S.; Hussey, S.; Musi, N. Elevated muscle TLR4 expression and metabolic endotoxemia in human aging. J. Gerontol. A Biol. Sci. Med. Sci. 2015, 70, 232-246. [CrossRef] [PubMed]

104. Delzenne, N.M.; Knudsen, C.; Beaumont, M.; Rodriguez, J.; Neyrinck, A.M.; Bindels, L.B. Contribution of the gut microbiota to the regulation of host metabolism and energy balance: A focus on the gut-liver axis. Proc. Nutr. Soc. 2019, 78, 319-328. [CrossRef]

105. Frost, R.A.N.; Lang, C.H. Lipopolysaccharide regulates proinflammatory cytokine expression in mouse myoblasts and skeletal muscle. Am. J. Physiol. Regul. Integr. Comp. Physiol. 2002, 283, R698-R709. [CrossRef]

106. Cuthbertson, D.; Smith, K.; Babraj, J.; Leese, G.; Waddell, T.; Atherton, P.; Wackerhage, H.; Taylor, P.M.; Rennie, M.J. Anabolic signaling deficits underlie amino acid resistance of wasting, aging muscle. FASEB J. 2005, 19, 422-424. [CrossRef]

107. Lustgarten, M.S.; Price, L.L.; Chale, A.; Fielding, R.A. Metabolites related to gut bacterial metabolism, peroxisome proliferator-activated receptor-alpha activation, and insulin sensitivity are associated with physical function in functionally-limited older adults. Aging Cell 2014, 13, 918-925. [CrossRef]

108. Wall, B.T.; Gorissen, S.H.; Pennings, B.; Koopman, R.; Groen, B.B.; Verdijk, L.B.; van Loon, L.J. Aging is accompanied by a blunted muscle protein synthetic response to protein ingestion. PLOS ONE 2015, 10, e0140903. [CrossRef]

109. Grosicki, G.J.; Fielding, R.A.; Lustgarten, M.S. Gut microbiota contribute to age-related changes in skeletal muscle size, composition, and function: Biological basis for a gut-muscle axis. Calcif. Tissue Int. 2018, 102, 433-442. [CrossRef]

110. Velloso, L.A.; Folli, F.; Saad, M.J. TLR4 at the crossroads of nutrients, gut microbiota, and metabolic inflammation. Endocr. Rev. 2015, 36, 245-271. [CrossRef]

111. Ni Lochlainn, M.; Bowyer, R.C.E.; Steves, C.J. Dietary protein and muscle in aging people: The potential role of the gut microbiome. Nutrients 2018, 10, 929. [CrossRef] [PubMed]

112. Ticinesi, A.; Tana, C.; Nouvenne, A. The intestinal microbiome and its relevance for functionality in older persons. Curr. Opin. Clin. Nutr. Metab. Care 2019, 22, 4-12. [CrossRef] [PubMed]

113. An, R.; Wilms, E.; Masclee, A.A.M.; Smidt, H.; Zoetendal, E.G.; Jonkers, D. Age-dependent changes in GI physiology and microbiota: Time to reconsider? Gut 2018, 67, 2213-2222. [CrossRef] [PubMed]

114. Schmidt, T.S.B.; Raes, J.; Bork, P. The human gut microbiome: From association to modulation. Cell 2018, 172, 1198-1215. [CrossRef]

115. Pasiakos, S.M. Metabolic advantages of higher protein diets and benefits of dairy foods on weight management, glycemic regulation, and bone. J. Food Sci. 2015, 80 (Suppl. 1), A2-A7. [CrossRef]

116. Morton, R.W.; Traylor, D.A.; Weijs, P.J.M.; Phillips, S.M. Defining anabolic resistance: Implications for delivery of clinical care nutrition. Curr. Opin. Crit. Care 2018, 24, 124-130. [CrossRef]

117. Fromentin, G.; Darcel, N.; Chaumontet, C.; Marsset-Baglieri, A.; Nadkarni, N.; Tome, D. Peripheral and central mechanisms involved in the control of food intake by dietary amino acids and proteins. Nutr. Res. Rev. 2012, 25, 29-39. [CrossRef]

118. Van der Klaauw, A.A.; Keogh, J.M.; Henning, E.; Trowse, V.M.; Dhillo, W.S.; Ghatei, M.A.; Farooqi, I.S. High protein intake stimulates postprandial GLP1 and PYY release. Obesity 2013, 21, 1602-1607. [CrossRef]

119. Ojha, U. Protein-induced satiation and the calcium-sensing receptor. Diabetes Metab. Syndr. Obes. 2018, 11, 45-51. [CrossRef]

120. Bliss, E.S.; Whiteside, E. The gut-brain axis, the human gut microbiota and their integration in the development of obesity. Front. Physiol. 2018, 9, 900. [CrossRef]

121. Weigle, D.S.; Breen, P.A.; Matthys, C.C.; Callahan, H.S.; Meeuws, K.E.; Burden, V.R.; Purnell, J.Q. A high-protein diet induces sustained reductions in appetite, ad libitum caloric intake, and body weight despite compensatory changes in diurnal plasma leptin and ghrelin concentrations. Am. J. Clin. Nutr. 2005, 82, 41-48. [CrossRef] [PubMed]

122. Erdmann, J.; Lippl, F.; Schusdziarra, V. Differential effect of protein and fat on plasma ghrelin levels in man. Regul. Pept. 2003, 116, 101-107. [CrossRef]

123. Shrestha, Y.B.; Wickwire, K.; Giraudo, S.Q. Direct effects of nutrients, acetylcholine, CCK, and insulin on ghrelin release from the isolated stomachs of rats. Peptides 2009, 30, 1187-1191. [CrossRef] [PubMed] 
124. Al Massadi, O.; Pardo, M.; Roca-Rivada, A.; Castelao, C.; Casanueva, F.F.; Seoane, L.M. Macronutrients act directly on the stomach to regulate gastric ghrelin release. J. Endocrinol. Investig. 2010, 33, 599-602. [CrossRef] [PubMed]

125. Mignone, L.E.; Wu, T.; Horowitz, M.; Rayner, C.K. Whey protein: The "whey" forward for treatment of type 2 diabetes? World J. Diabetes 2015, 6, 1274-1284. [CrossRef]

126. Bendtsen, L.Q.; Lorenzen, J.K.; Bendsen, N.T.; Rasmussen, C.; Astrup, A. Effect of dairy proteins on appetite, energy expenditure, body weight, and composition: A review of the evidence from controlled clinical trials. Adv. Nutr. 2013, 4, 418-438. [CrossRef]

127. Blouet, C.; Jo, Y.H.; Li, X.; Schwartz, G.J. Mediobasal hypothalamic leucine sensing regulates food intake through activation of a hypothalamus-brainstem circuit. J. Neurosci. 2009, 29, 8302-8311. [CrossRef]

128. Leitao-Goncalves, R.; Carvalho-Santos, Z.; Francisco, A.P.; Fioreze, G.T.; Anjos, M.; Baltazar, C.; Elias, A.P.; Itskov, P.M.; Piper, M.D.W.; Ribeiro, C. Commensal bacteria and essential amino acids control food choice behavior and reproduction. PLoS Biol. 2017, 15, e2000862. [CrossRef]

129. Paddon-Jones, D.; Leidy, H. Dietary protein and muscle in older persons. Curr. Opin. Clin. Nutr. Metab. Care 2014, 17, 5-11. [CrossRef]

130. Moore, D.R.; Churchward-Venne, T.A.; Witard, O.; Breen, L.; Burd, N.A.; Tipton, K.D.; Phillips, S.M. Protein ingestion to stimulate myofibrillar protein synthesis requires greater relative protein intakes in healthy older versus younger men. J. Gerontol. A Biol. Sci. Med. Sci. 2015, 70, 57-62. [CrossRef]

131. Breen, L.; Phillips, S.M. Skeletal muscle protein metabolism in the elderly: Interventions to counteract the 'anabolic resistance' of ageing. Nutr. Metab. 2011, 8, 68. [CrossRef] [PubMed]

132. Churchward-Venne, T.A.; Breen, L.; Di Donato, D.M.; Hector, A.J.; Mitchell, C.J.; Moore, D.R.; Stellingwerff, T.; Breuille, D.; Offord, E.A.; Baker, S.K.; et al. Leucine supplementation of a low-protein mixed macronutrient beverage enhances myofibrillar protein synthesis in young men: A double-blind, randomized trial. Am. J. Clin. Nutr. 2014, 99, 276-286. [CrossRef] [PubMed]

133. Witard, O.C.; Wardle, S.L.; Macnaughton, L.S.; Hodgson, A.B.; Tipton, K.D. Protein considerations for optimising skeletal muscle mass in healthy young and older adults. Nutrients 2016, 8, 181. [CrossRef]

134. Devries, M.C.; McGlory, C.; Bolster, D.R.; Kamil, A.; Rahn, M.; Harkness, L.; Baker, S.K.; Phillips, S.M. Leucine, not total protein, content of a supplement is the primary determinant of muscle protein anabolic responses in healthy older women. J. Nutr. 2018, 148, 1088-1095. [CrossRef]

135. Zhao, J.; Zhang, X.; Liu, H.; Brown, M.A.; Qiao, S. Dietary protein and gut microbiota composition and function. Curr. Protein Pept. Sci. 2019, 20, 145-154. [CrossRef] [PubMed]

136. Vaiserman, A.M.; Koliada, A.K.; Marotta, F. Gut microbiota: A player in aging and a target for anti-aging intervention. Ageing Res. Rev. 2017, 35, 36-45. [CrossRef] [PubMed]

137. Murton, A.J. Muscle protein turnover in the elderly and its potential contribution to the development of sarcopenia. Proc. Nutr. Soc. 2015, 74, 387-396. [CrossRef]

138. Tanner, R.E.; Brunker, L.B.; Agergaard, J.; Barrows, K.M.; Briggs, R.A.; Kwon, O.S.; Young, L.M.; Hopkins, P.N.; Volpi, E.; Marcus, R.L.; et al. Age-related differences in lean mass, protein synthesis and skeletal muscle markers of proteolysis after bed rest and exercise rehabilitation. J. Physiol. 2015, 593, 4259-4273. [CrossRef]

139. Portune, K.J.; Beaumont, M.; Davila, A.-M.; Tomé, D.; Blachier, F.; Sanz, Y. Gut microbiota role in dietary protein metabolism and health-related outcomes: The two sides of the coin. Trends Food Sci. Technol. 2016, 57, 213-232. [CrossRef]

140. Magee, E.A.R.; Hughes, R.; Cummings, J.H. Contribution of dietary protein to sulfide production in the large intestine: An in vitro and a controlled feeding study in humans. Am. J. Clin. Nutr. 2000, 72, 1488-1494. [CrossRef]

141. Davila, A.M.; Blachier, F.; Gotteland, M.; Andriamihaja, M.; Benetti, P.H.; Sanz, Y.; Tome, D. Intestinal luminal nitrogen metabolism: Role of the gut microbiota and consequences for the host. Pharmacol. Res. 2013, 68, 95-107. [CrossRef] [PubMed]

142. Metges, C.C. Contribution of microbial amino acids to amino acid homeostasis of the host. J. Nutr. 2000, 130, 1857S-1864S. [CrossRef] [PubMed]

143. Westerterp-Plantenga, M.S.; Lemmens, S.G.; Westerterp, K.R. Dietary protein-its role in satiety, energetics, weight loss and health. Br. J. Nutr. 2012, 108 (Suppl. 2), S105-S112. [CrossRef]

144. Pesta, D.H.; Samuel, V.T. A high-protein diet for reducing body fat: Mechanisms and possible caveats. Nutr. Metab. 2014, 11, 1-8. [CrossRef] [PubMed] 
145. Blachier, F.; Beaumont, M.; Portune, K.J.; Steuer, N.; Lan, A.; Audebert, M.; Khodorova, N.; Andriamihaja, M.; Airinei, G.; Benamouzig, R.; et al. High-protein diets for weight management: Interactions with the intestinal microbiota and consequences for gut health. A position paper by the my new gut study group. Clin. Nutr. 2019, 38, 1012-1022. [CrossRef]

146. Morowitz, M.J.; Carlisle, E.M.; Alverdy, J.C. Contributions of intestinal bacteria to nutrition and metabolism in the critically ill. Surg. Clin. N. Am. 2011, 91, 771-785. [CrossRef]

147. Windey, K.; De Preter, V.; Verbeke, K. Relevance of protein fermentation to gut health. Mol. Nutr. Food Res. 2012, 56, 184-196. [CrossRef]

148. Russell, W.R.; Gratz, S.W.; Duncan, S.H.; Holtrop, G.; Ince, J.; Scobbie, L.; Duncan, G.; Johnstone, A.M.; Lobley, G.E.; Wallace, R.J.; et al. High-protein, reduced-carbohydrate weight-loss diets promote metabolite profiles likely to be detrimental to colonic health. Am. J. Clin. Nutr. 2011, 93, 1062-1072. [CrossRef]

149. Lan, A.; Andriamihaja, M.; Blouin, J.M.; Liu, X.; Descatoire, V.; de Maredsous, C.D.; Davila, A.M.; Walker, F.; Tome, D.; Blachier, F. High-protein diet differently modifies intestinal goblet cell characteristics and mucosal cytokine expression in ileum and colon. J. Nutr. Biochem. 2015, 26, 91-98. [CrossRef]

150. Wang, T.J.; Larson, M.G.; Vasan, R.S.; Cheng, S.; Rhee, E.P.; McCabe, E.; Lewis, G.D.; Fox, C.S.; Jacques, P.F.; Fernandez, C.; et al. Metabolite profiles and the risk of developing diabetes. Nat. Med. 2011, 17, 448-453. [CrossRef]

151. Ridaura, V.K.; Faith, J.J.; Rey, F.E.; Cheng, J.; Duncan, A.E.; Kau, A.L.; Griffin, N.W.; Lombard, V.; Henrissat, B.; Bain, J.R.; et al. Gut microbiota from twins discordant for obesity modulate metabolism in mice. Science 2013, 341, 1241214. [CrossRef] [PubMed]

152. Zhao, X.; Han, Q.; Liu, Y.; Sun, C.; Gang, X.; Wang, G. The relationship between branched-chain amino acid related metabolomic signature and insulin resistance: A systematic review. J. Diabetes Res. 2016, 2016, 2794591. [CrossRef] [PubMed]

153. Bloomgarden, Z. Diabetes and branched-chain amino acids: What is the link? J. Diabetes 2018, 10, 350-352. [CrossRef] [PubMed]

154. Lotta, L.A.; Scott, R.A.; Sharp, S.J.; Burgess, S.; Luan, J.; Tillin, T.; Schmidt, A.F.; Imamura, F.; Stewart, I.D.; Perry, J.R.; et al. Genetic predisposition to an impaired metabolism of the branched-chain amino acids and risk of type 2 diabetes: A mendelian randomisation analysis. PLoS Med. 2016, 13, e1002179. [CrossRef] [PubMed]

155. Bergen, W.G.; Wu, G. Intestinal nitrogen recycling and utilization in health and disease. J. Nutr. 2009, 139, 821-825. [CrossRef]

156. Mu, C.; Yang, Y.; Yu, K.; Yu, M.; Zhang, C.; Su, Y.; Zhu, W. Alteration of metabolomic markers of amino-acid metabolism in piglets with in-feed antibiotics. Amino Acids 2017, 49, 771-781. [CrossRef]

157. Boudry, G.; Le Huërou-Luron, I.; Michel, C. Chapter 15 - Dietary Protein and Colonic Microbiota: Molecular Aspects. Mol. Nutr. Amino Acids Proteins 2016. [CrossRef]

158. Rios-Covian, D.; Ruas-Madiedo, P.; Margolles, A.; Gueimonde, M.; de Los Reyes-Gavilan, C.G.; Salazar, N. Intestinal short chain fatty acids and their link with diet and human health. Front. Microbiol. 2016, 7, 185. [CrossRef]

159. Mardinoglu, A.; Shoaie, S.; Bergentall, M.; Ghaffari, P.; Zhang, C.; Larsson, E.; Backhed, F.; Nielsen, J. The gut microbiota modulates host amino acid and glutathione metabolism in mice. Mol. Syst. Biol. 2015, 11, 834. [CrossRef]

160. Beaumont, M.; Portune, K.J.; Steuer, N.; Lan, A.; Cerrudo, V.; Audebert, M.; Dumont, F.; Mancano, G.; Khodorova, N.; Andriamihaja, M.; et al. Quantity and source of dietary protein influence metabolite production by gut microbiota and rectal mucosa gene expression: A randomized, parallel, double-blind trial in overweight humans. Am. J. Clin. Nutr. 2017, 106, 1005-1019. [CrossRef]

161. Tomova, A.; Bukovsky, I.; Rembert, E.; Yonas, W.; Alwarith, J.; Barnard, N.D.; Kahleova, H. The effects of vegetarian and vegan diets on gut microbiota. Front. Nutr. 2019, 6, 47. [CrossRef] [PubMed]

162. Cotillard, A.; Kennedy, S.P.; Kong, L.C.; Prifti, E.; Pons, N.; Le Chatelier, E.; Almeida, M.; Quinquis, B.; Levenez, F.; Galleron, N.; et al. Dietary intervention impact on gut microbial gene richness. Nature 2013, 500, 585-588. [CrossRef] [PubMed]

163. Reichardt, N.; Duncan, S.H.; Young, P.; Belenguer, A.; McWilliam Leitch, C.; Scott, K.P.; Flint, H.J.; Louis, P. Erratum: Phylogenetic distribution of three pathways for propionate production within the human gut microbiota. ISME J. 2014, 8, 1352. [CrossRef] 
164. Butteiger, D.N.; Hibberd, A.A.; McGraw, N.J.; Napawan, N.; Hall-Porter, J.M.; Krul, E.S. Soy protein compared with milk protein in a western diet increases gut microbial diversity and reduces serum lipids in golden syrian hamsters. J. Nutr. 2016, 146, 697-705. [CrossRef]

165. Kim, M.S.; Hwang, S.S.; Park, E.J.; Bae, J.W. Strict vegetarian diet improves the risk factors associated with metabolic diseases by modulating gut microbiota and reducing intestinal inflammation. Environ. Microbiol. Rep. 2013, 5, 765-775. [CrossRef]

166. Lopetuso, L.R.S.; Petito, V.; Gasbarrini, A. Commensal clostridia: Leading players in the maintenance of gut homeostasis. Gut Pathog. 2013, 5, 23. [CrossRef]

167. Huang, H.; Krishnan, H.B.; Pham, Q.; Yu, L.L.; Wang, T.T. Soy and gut microbiota: Interaction and implication for human health. J. Agric. Food Chem. 2016, 64, 8695-8709. [CrossRef]

168. Nakatani, A.; Li, X.; Miyamoto, J.; Igarashi, M.; Watanabe, H.; Sutou, A.; Watanabe, K.; Motoyama, T.; Tachibana, N.; Kohno, M.; et al. Dietary mung bean protein reduces high-fat diet-induced weight gain by modulating host bile acid metabolism in a gut microbiota-dependent manner. Biochem. Biophys. Res. Commun. 2018, 501, 955-961. [CrossRef]

169. Zhou, X.L.; Yan, B.B.; Xiao, Y.; Zhou, Y.M.; Liu, T.Y. Tartary buckwheat protein prevented dyslipidemia in high-fat diet-fed mice associated with gut microbiota changes. Food Chem. Toxicol. 2018, 119, $296-301$. [CrossRef]

170. Romond, M.G.; Bounouader, R.; Cortot, A.; Romond, C. Cell-free whey from milk fermented with bifidobacterium breve C50 used to modify the colonic microflora of healthy subjects. J. Dairy Sci. 1998, 81, 1229-1235. [CrossRef]

171. Meddah, A.T.; Yazourh, A.; Desmet, I.; Risbourg, B.; Verstraete, W.; Romond, M.B. The regulatory effects of whey retentate from bifidobacteria fermented milk on the microbiota of the Simulator of the Human Intestinal Microbial Ecosystem (SHIME). J. Appl. Microbiol. 2001, 91, 1110-1117. [CrossRef] [PubMed]

172. Sanchez-Moya, T.; Lopez-Nicolas, R.; Planes, D.; Gonzalez-Bermudez, C.A.; Ros-Berruezo, G.; Frontela-Saseta, C. In vitro modulation of gut microbiota by whey protein to preserve intestinal health. Food Funct. 2017, 8, 3053-3063. [CrossRef] [PubMed]

173. An, H.M.; Park, S.Y.L.; Kim, J.R.; Cha, M.K.; Lee, S.W.; Lim, H.T.; Kim, J.K.; Ha, N.J. Antiobesity and lipid-lowering effects of Bifidobacterium spp. in high fat diet-induced obese rats. Lipids Health Dis. 2011, 10, 116. [CrossRef] [PubMed]

174. Park, D.Y.; Ahn, Y.T.; Park, S.H.; Huh, C.S.; Yoo, S.R.; Yu, R.; Sung, M.K.; McGregor, R.A.; Choi, M.S. Supplementation of Lactobacillus curvatus HY7601 and Lactobacillus plantarum KY1032 in diet-induced obese mice is associated with gut microbial changes and reduction in obesity. PLoS ONE 2013, 8, e59470. [CrossRef] [PubMed]

175. Chen, Y.M.; Wei, L.; Chiu, Y.S.; Hsu, Y.J.; Tsai, T.Y.; Wang, M.F.; Huang, C.C. Lactobacillus plantarum TWK10 supplementation improves exercise performance and increases muscle mass in mice. Nutrients 2016, 8, 205. [CrossRef] [PubMed]

176. Isokpehi, R.D.; Simmons, S.S.; Johnson, M.O.; Payton, M. Genomic evidence for bacterial determinants influencing obesity development. Int. J. Environ. Res. Public Health 2017, 14, 345. [CrossRef]

177. Sprong, R.C.; Schonewille, A.J.; van der Meer, R. Dietary cheese whey protein protects rats against mild dextran sulfate sodium-induced colitis: Role of mucin and microbiota. J. Dairy Sci. 2010, 93, 1364-1371. [CrossRef]

178. Shi, J.; Tauriainen, E.; Martonen, E.; Finckenberg, P.; Ahlroos-Lehmus, A.; Tuomainen, A.; Pilvi, T.K.; Korpela, R.; Mervaala, E.M. Whey protein isolate protects against diet-induced obesity and fatty liver formation. Int. Dairy J. 2011, 21, 513-522. [CrossRef]

179. McAllan, L.; Skuse, P.; Cotter, P.D.; O'Connor, P.; Cryan, J.F.; Ross, R.P.; Fitzgerald, G.; Roche, H.M.; Nilaweera, K.N. Protein quality and the protein to carbohydrate ratio within a high fat diet influences energy balance and the gut microbiota in C57BL/6J mice. PLoS ONE 2014, 9, e88904. [CrossRef]

180. Holm, J.B.; Ronnevik, A.; Tastesen, H.S.; Fjaere, E.; Fauske, K.R.; Liisberg, U.; Madsen, L.; Kristiansen, K.; Liaset, B. Diet-induced obesity, energy metabolism and gut microbiota in C57BL/6J mice fed Western diets based on lean seafood or lean meat mixtures. J. Nutr. Biochem. 2016, 31, 127-136. [CrossRef]

181. Zhu, Y.; Li, H.; Xu, X.; Li, C.; Zhou, G. The gut microbiota in young and middle-aged rats showed different responses to chicken protein in their diet. BMC Microbiol. 2016, 16, 281. [CrossRef] [PubMed] 
182. Yang, Z.; Huang, S.; Zou, D.; Dong, D.; He, X.; Liu, N.; Liu, W.; Huang, L. Metabolic shifts and structural changes in the gut microbiota upon branched-chain amino acid supplementation in middle-aged mice. Amino Acids 2016, 48, 2731-2745. [CrossRef] [PubMed]

183. Hu, C.; Li, F.; Duan, Y.; Yin, Y.; Kong, X. Dietary supplementation with leucine or in combination with arginine decreases body fat weight and alters gut microbiota composition in finishing pigs. Front. Microbiol. 2019, 10, 1767. [CrossRef] [PubMed]

184. Yu, H.; Guo, Z.; Shen, S.; Shan, W. Effects of taurine on gut microbiota and metabolism in mice. Amino Acids 2016, 48, 1601-1617. [CrossRef]

185. Moreno-Perez, D.; Bressa, C.; Bailen, M.; Hamed-Bousdar, S.; Naclerio, F.; Carmona, M.; Perez, M.; Gonzalez-Soltero, R.; Montalvo-Lominchar, M.G.; Carabana, C.; et al. Effect of a protein supplement on the gut microbiota of endurance athletes: A randomized, controlled, double-blind pilot study. Nutrients 2018, 10, 337. [CrossRef]

186. Spitze, A.R.W.; Rogers, Q.R.; Fascetti, A.J. Taurine concentrations in animal feed ingredients; cooking influences taurine content. J. Anim. Physiol. Anim. Nutr. 2003, 87, 251-262. [CrossRef]

187. Kim, C.H.; Park, J.; Kim, M. Gut microbiota-derived short-chain Fatty acids, T cells, and inflammation. Immune Netw. 2014, 14, 277-288. [CrossRef]

188. Park, J.S.; Lee, E.J.; Lee, J.C.; Kim, W.K.; Kim, H.S. Anti-inflammatory effects of short chain fatty acids in IFN-gamma-stimulated RAW 264.7 murine macrophage cells: Involvement of NF-kappaB and ERK signaling pathways. Int. Immunopharmacol. 2007, 7, 70-77. [CrossRef]

189. Petropoulou, K.; Chambers, E.S.; Morrison, D.J.; Preston, T.; Godsland, I.F.; Wilde, P.; Narbad, A.; Parker, R.; Salt, L.; Morris, V.J.; et al. Identifying crop variants with high resistant starch content to maintain healthy glucose homeostasis. Nutr. Bull. 2016, 41, 372-377. [CrossRef]

190. Chambers, E.S.; Byrne, C.S.; Morrison, D.J.; Murphy, K.G.; Preston, T.; Tedford, C.; Garcia-Perez, I.; Fountana, S.; Serrano-Contreras, J.I.; Holmes, E.; et al. Dietary supplementation with inulin-propionate ester or inulin improves insulin sensitivity in adults with overweight and obesity with distinct effects on the gut microbiota, plasma metabolome and systemic inflammatory responses: A randomised cross-over trial. Gut 2019, 68, 1430-1438. [CrossRef]

191. Larsen, N.; Vogensen, F.K.; van den Berg, F.W.; Nielsen, D.S.; Andreasen, A.S.; Pedersen, B.K.; Al-Soud, W.A.; Sorensen, S.J.; Hansen, L.H.; Jakobsen, M. Gut microbiota in human adults with type 2 diabetes differs from non-diabetic adults. PLoS ONE 2010, 5, e9085. [CrossRef] [PubMed]

192. Karlsson, F.H.; Tremaroli, V.; Nookaew, I.; Bergstrom, G.; Behre, C.J.; Fagerberg, B.; Nielsen, J.; Backhed, F. Gut metagenome in European women with normal, impaired and diabetic glucose control. Nature 2013, 498, 99-103. [CrossRef] [PubMed]

193. Shen, Z.; Zhu, C.; Quan, Y.; Yang, J.; Yuan, W.; Yang, Z.; Wu, S.; Luo, W.; Tan, B.; Wang, X. Insights into Roseburia intestinalis which alleviates experimental colitis pathology by inducing anti-inflammatory responses. J. Gastroenterol. Hepatol. 2018, 33, 1751-1760. [CrossRef] [PubMed]

194. Koeth, R.A.; Wang, Z.; Levison, B.S.; Buffa, J.A.; Org, E.; Sheehy, B.T.; Britt, E.B.; Fu, X.; Wu, Y.; Li, L.; et al. Intestinal microbiota metabolism of L-carnitine, a nutrient in red meat, promotes atherosclerosis. Nat. Med. 2013, 19, 576-585. [CrossRef] [PubMed]

195. Dumas, M.E.; Rothwell, A.R.; Hoyles, L.; Aranias, T.; Chilloux, J.; Calderari, S.; Noll, E.M.; Pean, N.; Boulange, C.L.; Blancher, C.; et al. Microbial-host co-metabolites are prodromal markers predicting phenotypic heterogeneity in behavior, obesity, and impaired glucose tolerance. Cell Rep. 2017, 20, 136-148. [CrossRef] [PubMed]

196. Cho, C.E.; Taesuwan, S.; Malysheva, O.V.; Bender, E.; Tulchinsky, N.F.; Yan, J.; Sutter, J.L.; Caudill, M.A. Trimethylamine-N-oxide (TMAO) response to animal source foods varies among healthy young men and is influenced by their gut microbiota composition: A randomized controlled trial. Mol. Nutr. Food Res. 2017, 61. [CrossRef] [PubMed]

197. Landfald, B.; Valeur, J.; Berstad, A.; Raa, J. Microbial trimethylamine-N-oxide as a disease marker: Something fishy? Microb. Ecol. Health Dis. 2017, 28, 1327309. [CrossRef]

198. Fielding, R.A.; Reeves, A.R.; Jasuja, R.; Liu, C.; Barrett, B.B.; Lustgarten, M.S. Muscle strength is increased in mice that are colonized with microbiota from high-functioning older adults. Exp. Gerontol. 2019, 127, 110722. [CrossRef] 
199. Lahiri, S.K.; Garcia-Perez, I.; Reza, M.M.; Martin, K.A.; Kundu, P.; Cox, L.M.; Selkrig, J.; Posma, J.M.; Zhang, H.; Padmanabhan, P.; et al. The gut microbiota influences skeletal muscle mass and function in mice. Sci. Transl. Med. 2019, 11, eaan5662. [CrossRef]

200. Zhu, Y.; Lin, X.; Li, H.; Li, Y.; Shi, X.; Zhao, F.; Xu, X.; Li, C.; Zhou, G. Intake of meat proteins substantially increased the relative abundance of genus lactobacillus in rat feces. PLoS ONE 2016, 11, e0152678. [CrossRef]

201. Jager, R.; Mohr, A.E.; Carpenter, K.C.; Kerksick, C.M.; Purpura, M.; Moussa, A.; Townsend, J.R.; Lamprecht, M.; West, N.P.; Black, K.; et al. International society of sports nutrition position stand: Probiotics. J. Int. Soc. Sports Nutr. 2019, 16, 62. [CrossRef] [PubMed]

202. Jager, R.; Purpura, M.; Farmer, S.; Cash, H.A.; Keller, D. Probiotic bacillus coagulans GBI-30, 6086 improves protein absorption and utilization. Probiotics. Antimicrob. Proteins 2018, 10, 611-615. [CrossRef] [PubMed]

203. Jayanama, K.; Theou, O. Effects of probiotics and prebiotics on frailty and ageing: A narrative review. Curr. Clin. Pharmacol. 2019. [CrossRef] [PubMed]

204. Wong, M.W.; Yi, C.H.; Liu, T.T.; Lei, W.Y.; Hung, J.S.; Lin, C.L.; Lin, S.Z.; Chen, C.L. Impact of vegan diets on gut microbiota: An update on the clinical implications. Ci Ji Yi Xue Za Zhi 2018, 30, 200-203. [CrossRef] [PubMed]

205. Mills, S.; Stanton, C.; Lane, J.A.; Smith, G.J.; Ross, R.P. Precision nutrition and the microbiome, part I: Current state of the science. Nutrients 2019, 11, 923. [CrossRef]

206. Najjar, R.S.; Feresin, R.G. Plant-based diets in the reduction of body fat: Physiological effects and biochemical insights. Nutrients 2019, 11, 2712. [CrossRef]

207. Puiman, P.; Stoll, B.; Molbak, L.; de Bruijn, A.; Schierbeek, H.; Boye, M.; Boehm, G.; Renes, I.; van Goudoever, J.; Burrin, D. Modulation of the gut microbiota with antibiotic treatment suppresses whole body urea production in neonatal pigs. Am. J. Physiol. Gastrointest. Liver Physiol. 2013, 304, G300-G310. [CrossRef]

208. Russell, W.R.; Duncan, S.H.; Scobbie, L.; Duncan, G.; Cantlay, L.; Calder, A.G.; Anderson, S.E.; Flint, H.J. Major phenylpropanoid-derived metabolites in the human gut can arise from microbial fermentation of protein. Mol. Nutr. Food Res. 2013, 57, 523-535. [CrossRef]

209. Rowland, I.; Gibson, G.; Heinken, A.; Scott, K.; Swann, J.; Thiele, I.; Tuohy, K. Gut microbiota functions: Metabolism of nutrients and other food components. Eur. J. Nutr. 2018, 57, 1-24. [CrossRef]

210. Depommier, C.; Everard, A.; Druart, C.; Plovier, H.; Van Hul, M.; Vieira-Silva, S.; Falony, G.; Raes, J.; Maiter, D.; Delzenne, N.M.; et al. Supplementation with Akkermansia muciniphila in overweight and obese human volunteers: A proof-of-concept exploratory study. Nat. Med. 2019, 25, 1096-1103. [CrossRef]

211. Everard, A.; Belzer, C.; Geurts, L.; Ouwerkerk, J.P.; Druart, C.; Bindels, L.B.; Guiot, Y.; Derrien, M.; Muccioli, G.G.; Delzenne, N.M.; et al. Cross-talk between Akkermansia muciniphila and intestinal epithelium controls diet-induced obesity. Proc. Natl. Acad. Sci. USA 2013, 110, 9066-9071. [CrossRef] [PubMed]

212. Shin, N.R.; Lee, J.C.; Lee, H.Y.; Kim, M.S.; Whon, T.W.; Lee, M.S.; Bae, J.W. An increase in the Akkermansia spp. population induced by metformin treatment improves glucose homeostasis in diet-induced obese mice. Gut 2014, 63, 727-735. [CrossRef] [PubMed]

213. Chambers, E.S.; Viardot, A.; Psichas, A.; Morrison, D.J.; Murphy, K.G.; Zac-Varghese, S.E.; MacDougall, K.; Preston, T.; Tedford, C.; Finlayson, G.S.; et al. Effects of targeted delivery of propionate to the human colon on appetite regulation, body weight maintenance and adiposity in overweight adults. Gut 2015, 64, 1744-1754. [CrossRef] [PubMed]

214. Den Besten, G.; van Eunen, K.; Groen, A.K.; Venema, K.; Reijngoud, D.J.; Bakker, B.M. The role of short-chain fatty acids in the interplay between diet, gut microbiota, and host energy metabolism. J. Lipid Res. 2013, 54, 2325-2340. [CrossRef] [PubMed]

215. Verbeke, K.A.; Boobis, A.R.; Chiodini, A.; Edwards, C.A.; Franck, A.; Kleerebezem, M.; Nauta, A.; Raes, J.; van Tol, E.A.; Tuohy, K.M. Towards microbial fermentation metabolites as markers for health benefits of prebiotics. Nutr. Res. Rev. 2015, 28, 42-66. [CrossRef] [PubMed]

216. Dhingra, D.; Michael, M.; Rajput, H.; Patil, R.T. Dietary fibre in foods: A review. J. Food Sci. Technol. 2012, 49, 255-266. [CrossRef]

217. Gibson, R.; Eriksen, R.; Chambers, E.; Gao, H.; Aresu, M.; Heard, A.; Chan, Q.; Elliott, P.; Frost, G. Intakes and food sources of dietary fibre and their associations with measures of body composition and inflammation in UK adults: Cross-sectional analysis of the airwave health monitoring study. Nutrients 2019, 11, 1839. [CrossRef] 
218. Fayet-Moore, F.; Cassettari, T.; Tuck, K.; McConnell, A.; Petocz, P. Dietary fibre intake in australia. Paper I: Associations with demographic, socio-economic, and anthropometric factors. Nutrients 2018, 10, 599. [CrossRef]

219. Harris, H.C.; Edwards, C.A.; Morrison, D.J. Impact of glycosidic bond configuration on short chain fatty acid production from model fermentable carbohydrates by the human gut microbiota. Nutrients 2017, 9, 26. [CrossRef]

220. Chambers, E.S.; Preston, T.; Frost, G.; Morrison, D.J. Role of gut microbiota-generated short-chain fatty acids in metabolic and cardiovascular health. Curr. Nutr. Rep. 2018, 7, 198-206. [CrossRef]

221. Cox, M.A.; Jackson, J.; Stanton, M.; Rojas-Triana, A.; Bober, L.; Laverty, M.; Yang, X.; Zhu, F.; Liu, J.; Wang, S.; et al. Short-chain fatty acids act as antiinflammatory mediators by regulating prostaglandin $\mathrm{E}(2)$ and cytokines. World J. Gastroenterol. 2009, 15, 5549-5557. [CrossRef] [PubMed]

222. Canfora, E.E.; Meex, R.C.R.; Venema, K.; Blaak, E.E. Gut microbial metabolites in obesity, NAFLD and T2DM. Nat. Rev. Endocrinol. 2019, 15, 261-273. [CrossRef] [PubMed]

223. Sukkar, A.H.; Lett, A.M.; Frost, G.; Chambers, E.S. Regulation of energy expenditure and substrate oxidation by short-chain fatty acids. J. Endocrinol. 2019, 242, R1-R8. [CrossRef] [PubMed]

224. Frampton, J.; Murphy, K.G.; Frost, G.; Chambers, E.S. Short-chain fatty acids as potential regulators of skeletal muscle metabolism and function. Nat. Metab. 2020. [CrossRef]

225. Alamshah, A.; Spreckley, E.; Norton, M.; Kinsey-Jones, J.S.; Amin, A.; Ramgulam, A.; Cao, Y.; Johnson, R.; Saleh, K.; Akalestou, E.; et al. L-phenylalanine modulates gut hormone release and glucose tolerance, and suppresses food intake through the calcium-sensing receptor in rodents. Int. J. Obes. (Lond.) 2017, 41, 1693-1701. [CrossRef]

226. Amin, A.; Neophytou, C.; Thein, S.; Martin, N.M.; Alamshah, A.; Spreckley, E.; Bloom, S.R.; Murphy, K.G. L-arginine increases postprandial circulating GLP-1 and PYY levels in humans. Obesity 2018, 26, 1721-1726. [CrossRef]

227. Chambers, E.S.; Viardot, A.; Psichas, A.; Morrison, D.J.; Murphy, K.G.; Zac-Varghese, S.E.K.; MacDougall, K.; Preston, T.; Tedford, M.C.; Bell, J.D.; et al. Targeted delivery of propionate to the human colon prevents body weight and intra-abdominal adipose tissue gain in overweight adults. Proc. Nutr. Soc. 2014, 73. [CrossRef]

228. Chimerel, C.; Emery, E.; Summers, D.K.; Keyser, U.; Gribble, F.M.; Reimann, F. Bacterial metabolite indole modulates incretin secretion from intestinal enteroendocrine L cells. Cell Rep. 2014, 9, 1202-1208. [CrossRef]

229. Spreckley, E.; Murphy, K.G. The L-cell in nutritional sensing and the regulation of appetite. Front. Nutr. 2015, 2, 23. [CrossRef]

230. Williams, B.B.; Van Benschoten, A.H.; Cimermancic, P.; Donia, M.S.; Zimmermann, M.; Taketani, M.; Ishihara, A.; Kashyap, P.C.; Fraser, J.S.; Fischbach, M.A. Discovery and characterization of gut microbiota decarboxylases that can produce the neurotransmitter tryptamine. Cell Host Microbe 2014, 16, 495-503. [CrossRef]

231. Yano, J.M.; Yu, K.; Donaldson, G.P.; Shastri, G.G.; Ann, P.; Ma, L.; Nagler, C.R.; Ismagilov, R.F.; Mazmanian, S.K.; Hsiao, E.Y. Indigenous bacteria from the gut microbiota regulate host serotonin biosynthesis. Cell 2015, 163. [CrossRef]

232. Dagbasi, A.; Lett, A.M.; Murphy, K.; Frost, G. Understanding the interplay between food structure, intestinal bacterial fermentation and appetite control. Proc. Nutr. Soc. 2020, 1-17. [CrossRef] [PubMed]

233. Norton, M.; Murphy, K.G. Targeting gastrointestinal nutrient sensing mechanisms to treat obesity. Curr. Opin. Pharmacol. 2017, 37, 16-23. [CrossRef] [PubMed]

234. Byrne, C.S.; Chambers, E.S.; Alhabeeb, H.; Chhina, N.; Morrison, D.J.; Preston, T.; Tedford, C.; Fitzpatrick, J.; Irani, C.; Busza, A.; et al. Increased colonic propionate reduces anticipatory reward responses in the human striatum to high-energy foods. Am. J. Clin. Nutr. 2016, 104, 5-14. [CrossRef] [PubMed]

235. Yau, Y.H.; Potenza, M.N. Stress and eating behaviors. Minerva Endocrinol. 2013, 38, 255-267.

236. Ford, A.L.; Nagulesapillai, V.; Piano, A.; Auger, J.; Girard, S.A.; Christman, M.; Tompkins, T.A.; Dahl, W.J. Microbiota stability and gastrointestinal tolerance in response to a high-protein diet with and without a prebiotic, probiotic, and synbiotic: A randomized, double-blind, placebo-controlled trial in older women. J. Acad. Nutr. Diet. 2020, 120, 500-516. [CrossRef]

237. Sergeev, I.N.; Aljutaily, T.; Walton, G.; Huarte, E. Effects of synbiotic supplement on human gut microbiota, body composition and weight loss in obesity. Nutrients 2020, 12, 222. [CrossRef] 
238. Brinkworth, G.D.; Noakes, M.; Clifton, P.M.; Bird, A.R. Comparative effects of very low-carbohydrate, high-fat and high-carbohydrate, low-fat weight-loss diets on bowel habit and faecal short-chain fatty acids and bacterial populations. Br. J. Nutr. 2009, 101, 1493-1502. [CrossRef]

239. Duncan, S.H.; Belenguer, A.; Holtrop, G.; Johnstone, A.M.; Flint, H.J.; Lobley, G.E. Reduced dietary intake of carbohydrates by obese subjects results in decreased concentrations of butyrate and butyrate-producing bacteria in feces. Appl. Environ. Microbiol. 2007, 73, 1073-1078. [CrossRef]

240. Salonen, A.; Lahti, L.; Salojarvi, J.; Holtrop, G.; Korpela, K.; Duncan, S.H.; Date, P.; Farquharson, F.; Johnstone, A.M.; Lobley, G.E.; et al. Impact of diet and individual variation on intestinal microbiota composition and fermentation products in obese men. ISME J. 2014, 8, 2218-2230. [CrossRef]

241. Walker, A.W.; Ince, J.; Duncan, S.H.; Webster, L.M.; Holtrop, G.; Ze, X.; Brown, D.; Stares, M.D.; Scott, P.; Bergerat, A.; et al. Dominant and diet-responsive groups of bacteria within the human colonic microbiota. ISME J. 2011, 5, 220-230. [CrossRef] [PubMed]

242. Murtaza, N.; Burke, L.M.; Vlahovich, N.; Charlesson, B.; O’Neill, H.; Ross, M.L.; Campbell, K.L.; Krause, L.; Morrison, M. The effects of dietary pattern during intensified training on stool microbiota of elite race walkers. Nutrients 2019, 11, 261. [CrossRef] [PubMed]

243. Li, Q.; Lauber, C.L.; Czarnecki-Maulden, G.; Pan, Y.; Hannah, S.S. Effects of the dietary protein and carbohydrate ratio on gut microbiomes in dogs of different body conditions. mBio 2017, 8. [CrossRef] [PubMed]

244. Vidal-Lletjos, S.; Andriamihaja, M.; Blais, A.; Grauso, M.; Lepage, P.; Davila, A.M.; Viel, R.; Gaudichon, C.; Leclerc, M.; Blachier, F.; et al. Dietary protein intake level modulates mucosal healing and mucosa-adherent microbiota in mouse model of colitis. Nutrients 2019, 11, 514. [CrossRef]

245. Madsen, L.; Myrmel, L.S.; Fjaere, E.; Liaset, B.; Kristiansen, K. Links between Dietary protein sources, the gut microbiota, and obesity. Front. Physiol. 2017, 8, 1047. [CrossRef]

(C) 2020 by the authors. Licensee MDPI, Basel, Switzerland. This article is an open access article distributed under the terms and conditions of the Creative Commons Attribution (CC BY) license (http://creativecommons.org/licenses/by/4.0/). 